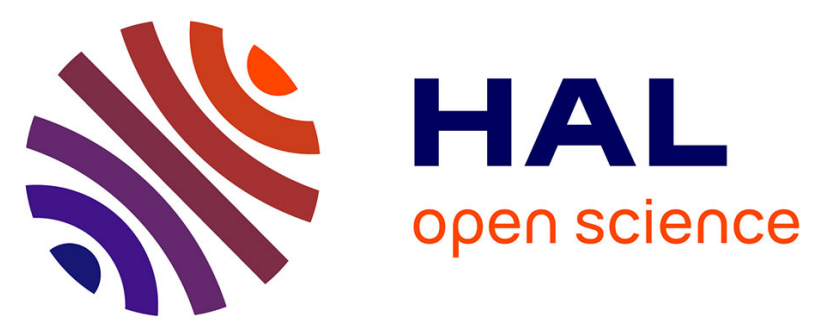

\title{
FVIII at the crossroad of coagulation, bone and immune biology: emerging evidence biological activities beyond hemostasis
}

\author{
Marie Cadé, Javier Munoz-Garcia, Antoine Babuty, M. Marc Fouassier, \\ Marie-Françoise Heymann, Paul E Monahan, Dominique Heymann
}

\section{To cite this version:}

Marie Cadé, Javier Munoz-Garcia, Antoine Babuty, M. Marc Fouassier, Marie-Françoise Heymann, et al.. FVIII at the crossroad of coagulation, bone and immune biology: emerging evidence biological activities beyond hemostasis: Factor VIIIbeyond hemostasis. Drug Discovery Today, 2021, pp.S13596446(21)00321-4. 10.1016/j.drudis.2021.07.015 . inserm-03298299

\section{HAL Id: inserm-03298299 https://www.hal.inserm.fr/inserm-03298299}

Submitted on 23 Jul 2021

HAL is a multi-disciplinary open access archive for the deposit and dissemination of scientific research documents, whether they are published or not. The documents may come from teaching and research institutions in France or abroad, or from public or private research centers.
L'archive ouverte pluridisciplinaire HAL, est destinée au dépôt et à la diffusion de documents scientifiques de niveau recherche, publiés ou non, émanant des établissements d'enseignement et de recherche français ou étrangers, des laboratoires publics ou privés. 
archives-ouvertes

\title{
FVIII at the crossroad of coagulation, bone and immune biology: emerging evidence biological activities beyond hemostasis
}

\author{
Marie Cadé, Javier Munoz-Garcia, Antoine Babuty, M. Marc Fouassier, \\ Marie-Françoise Heymann, Paul Monahan, Dominique Heymann
}

\section{To cite this version:}

Marie Cadé, Javier Munoz-Garcia, Antoine Babuty, M. Marc Fouassier, Marie-Françoise Heymann, et al.. FVIII at the crossroad of coagulation, bone and immune biology: emerging evidence biological activities beyond hemostasis. Drug Discovery Today, Elsevier, In press. inserm-03298299

\section{HAL Id: inserm-03298299 https://www.hal.inserm.fr/inserm-03298299}

Submitted on 23 Jul 2021

HAL is a multi-disciplinary open access archive for the deposit and dissemination of scientific research documents, whether they are published or not. The documents may come from teaching and research institutions in France or abroad, or from public or private research centers.
L'archive ouverte pluridisciplinaire HAL, est destinée au dépôt et à la diffusion de documents scientifiques de niveau recherche, publiés ou non, émanant des établissements d'enseignement et de recherche français ou étrangers, des laboratoires publics ou privés. 
FVIII at the crossroad of coagulation, bone and immune biology: emerging evidence biological activities beyond hemostasis

Marie Cadé ${ }^{1}$, Javier Muñoz-Garcia ${ }^{1}$, Antoine Babuty ${ }^{1,2}$, Marc Fouassier ${ }^{2}$, Marie-Francoise Heymann ${ }^{1}$, Paul E. Monahan ${ }^{3}$, Dominique Heymann ${ }^{1,4, *}$

${ }^{1}$ Université de Nantes, INSERM, Institut de Cancérologie de l'Ouest, Saint-Herblain, 44805, France.

${ }^{2}$ Department of Haemostasis, CHU de Nantes, France.

${ }^{3}$ Spark Therapeutics, Philadelphia, PA, USA.

${ }^{4}$ University of Sheffield, Department of Oncology and Metabolism, Sheffield, UK.

Short title for the running head: Factor VIII beyond hemostasis

Keywords: FVIII; VWF; Coagulation cascade; Hemostasis; Bone remodeling; Immune regulation; Endothelial cells; Vascularization; Macrophages

*Corresponding Authors:

Dominique Heymann

Institut de Cancérologie de l'Ouest

Blvd Jacques Monod

44805 Saint-Herblain, France

Email: dominique.heymann@univ-nantes.fr

Tel: +33 (0) 240679841 


\section{Word teaser}

In addition to its hemostatic function, FVIII may have multiple biological activities in bone, immune cells and vascular system. The present review gives a brief overview of the current demonstrated and hypothesized or even controversial activities of FVIII and its recent interactions with membrane receptors. 


\begin{abstract}
Hemophilia $\mathrm{A}$ is an X-linked hereditary disorder related to the deficiency of coagulation factor VIII (FVIII) leading to spontaneous bleeding episodes particularly into joints and muscles. FVIII deficiency has been associated with altered bone remodeling, dysregulated macrophage polarization, and inflammatory processes combined with neoformation of abnormal blood vessels. Treatment based on FVIII can lead to the development of inhibitors that render FVIII concentrate infusion ineffective. In this context, hemophilia has entered a new therapeutic era with the development of new drugs (e.g. Emicizumab) to restore the hemostatic balance by bypassing pathologic acquired antibodies. The present review aims to discuss the potential extrahemostatic functions of FVIII which may be crucial information for defining the future therapies in hemophilia.
\end{abstract}




\section{Introduction}

Hemophilia A (HA) is an inherited bleeding disorder related to a functional and/or quantitative alteration in the expression of coagulation factor (F) VIII (FVIII). HA is a rare genetic disease affecting approximately 1 in 5,000 men, with recessive inheritance linked to the $\mathrm{X}$ chromosome. In about $2 / 3$ of cases, the mutation comes from family inheritance, and in the remaining third, there is sporadic onset of the disease. Although mens are preferentially affected, rare cases of HA in women have been reported. These cases may be due to receiving two mutated $\mathrm{X}$ chromosomes (the mother carrying hemophilia A and an affected father), or inactivation of the $\mathrm{X}$ chromosome carrying the healthy allele [1-3]. The pivotal role played by FVIII in the coagulation cascade is now well-established [4-7] (Supplementary Figure 1). The biology of FVIII is closely intertwined with those of von Willebrand Factor (VWF). VWF is a multimeric glycoprotein essential for maintaining the integrity of FVIII in the bloodstream. VWF binds to FVIII in a non-covalent manner and is its main molecular partner. It serves as a chaperone for FVIII and is therefore a crucial element because it protects the FVIII in the blood and increases both its half-life and its bioavailability [8]. The FVIII-VWF interaction is highly dynamic, with rapid association and dissociation rates [8].

In HA, FVIII deficiency is directly associated with alteration to the coagulation process. The clinical manifestations of HA depend on the severity of the disease, which is directly related to the coagulant activity of FVIII, measured in plasma. Patients with baseline coagulant FVIII activity of less than $1 \%$ have a severe form of the disease, while coagulant FVIII activity between 1 and $5 \%$ is observed in around $20 \%$ of patients and is considered moderate disease. The mild form then concerns $40 \%$ of patients, with FVIII activity of up to $40 \%$. The severe and moderate forms of HA are associated with recurrent and spontaneous bleeding, mainly in the muscles and joints [9]. The recurrence of hematomas and hemarthrosis can lead to the 
development of disabling hemophilic arthropathies, and in some cases can be life-threatening, especially in case of cerebral haemorrhage [10]. Until recent decades, concern regarding the risk of causing recurrent bleeding and the sequelae of hemarthroses and other hemorrhages resulted in a sedentary lifestyle for HA patients. Fortunately, the development and availability of prophylactic treatments based on FVIII substitutes has allowed this to change [9].

More recently, research initiatives led to the development of non-substitutive products of FVIII which act as a mimetic to FVIII [e.g Emicizumab (Roche) or Mim8 (NovoNordisk)] or seek to restore the hemostatic balance by compensating the decreased thrombin generation [e.g fitusiran (Sanofi), and TFPI or protein $\mathrm{S}$ inhibitors]. There are now some evidences that FVIII contribute to the regulation of bone metabolism and in inflammation. However, it has not been established whether these effects require FVIII itself, or are mediated by thrombin and/or factor Xa (FXa), whose deficiencies are byproducts of FVIII. The answer to this key question will allow to better define the long-term therapeutic approaches of HA (substitutive versus non-substitutive therapies) to know whether increased thrombin generation will replace all effects of FVIII or only hemostatic effects. That will determine whether FVIII can be eliminated with no deleterious consequence (e.g. dysregulation of bone loss) as long as downstream effects are maintained. After a brief description of the past and current therapeutic approaches of HA, the present review aims to describe the emerging and controversial evidences of extra-hemostatic activities of FVIII.

\section{Hemophilia A Therapies: Past and Present therapies for restoring the hemostatic balance}

Prior to the 1970s, the treatment of haemophilia was based on the use of cryoprecipitate and fresh frozen plasma [11]. Highly purified clotting factor concentrates from fractionated 
human plasma and then synthesized by genetic engineering (recombinant FVIII) were then proposed (Table 1) [12]. Since 2010, technological advances have made it possible to modify the structure of these proteins, allowing to extent their half-life. They have contributed, for reducing the number of prophylactic injections in patients, and for preventing the occurrence of bleeding, trough a higher residual factor level [13-17] (Table 1). Gene therapy was also proposed for treating FVIII deficiency $[18,19]$. Clinical trials are ongoing but the fact that the vectors used are common viruses, encountered by many people, complicates the use of gene therapy as antibodies to the vector are common [20] (Table 1). The major complication of FVIII replacement therapies is the development of anti-FVIII alloantibodies (called inhibitor) $[21,22]$. It occurs in $25-35 \%$ cases of severe haemophilia A with a higher frequency for the patients treated by recombinant FVIII (37.3\%) than those treated by plasma-derived FVIII (23.2\%) [23] even if there is discrepancies between the studies [23,24]. These clinically complex situations to manage have oriented research towards the development of nonsubstitutive therapies, with the aim of restoring exclusively the hemostatic balance.

Emicizumab is a bispecific humanized monoclonal antibody used in HA with a very long half-life (28 days) (Table 1). It binds to FIXa and FX to restore the function of cofactor VIIIa necessary for effective hemostasis [25]. Without any structural relationship or sequence homology with FVIII, it is not a target for anti-FVIII antibodies. Other non-substitutive treatments modifying the hemostatic balance include fitusiran, an antithrombin inhibitor that is a small interfering RNA that penetrates hepatocytes and inhibits antithrombin synthesis [26]. Other molecules target Tissue Factor Pathway Inhibitor (TFPI), a glycoprotein that represses clotting by inhibiting the tissue factor-FVIIa-FXa complex [27]. Whether it is crucial to restore the hemostatic balance in HA patients to reduce the bleeding disorder caused by deficient activity of FVIII, and consequently by severely deficiency of thrombin 
generation, recent insights identified potential new activities of FVIII outside the scope of hemostasis.

\section{Contribution of FVIII in the control of bone remodeling}

Multiple clinical studies have described the risk of low bone mineral density (BMD) in HA adult and pediatric populations (Table 2). These studies demonstrate the high prevalence of low BMD in moderate and severe HA patients, $27 \%$ of whom exhibit an osteoporotic phenotype and $43 \%$ of osteopenia associated with abnormal levels of markers for bone metabolism and circulating cytokines in blood [56-58]. Low BMD markedly increases the risk of fracture in HA patients [59,60]. The etiology of the low BMD in HA patients was initially and logically assumed to be associated with a sedentary lifestyle along with the development of hemarthrosis. New prophylactic treatments based on FVIII replacement result in more consistent hemostatic protection and have durably modified the lifestyle of HA patients. However, FVIII replacement partly prevents the loss of BMD in patients with a severe form of the disease [54-56].

Bone remodeling is a regular cycle composed of phases of bone formation and resorption, mediated by osteoblasts and osteoclasts respectively. Both bone cell types communicate by using soluble factors and, more particularly, a molecular triad belonging to the Tunor Necrosis Factor (TNF)/TNF receptor superfamilies which controls the differentiation and activation of osteoclasts. This molecular triad includes: i) the Receptor Activator of Nuclear Factor kappa B (RANK) expressed at the surface of osteoclasts; ii) RANK ligand (RANKL); and iii) Osteoprotegerin (OPG), an ubiquitinary soluble protein which acts as a decoy receptor for RANKL. RANKL expressed by osteoblasts and stromal cells binds to RANK and induces the differentiation and activation of osteoclasts. OPG released by osteoblasts binds to 
RANKL and blocks the binding of RANKL to RANK and consequently interrupts the associated NFkB signaling pathway. In addition to being an inhibitor of osteoclast formation and bone resorption, OPG is a biological modulator of endothelial cells (e.g. the promotion of vascular tubes) [64-66]. Demonstrating that OPG was co-localized and physically associated with VWF in the Weibel-Palade bodies was the first evidence of a relationship between a hemostatic factor and a bone remodeling regulator [67]. OPG provides a functional link between the FVIII/VWF complex and bone cell differentiation has been demonstrated [68]. In 2009, Baud'huin et al. revealed that FVIII-VWF complex inhibits the RANKL-induced osteoclastogenesis and resorption activity of osteoclasts in murine and human models. FVIIIVWF complex binds to OPG and this interaction occurs through the A1 domain of VWF [69]. FVIII-VWF complex also binds to immobilized RANKL whereas recombinant FVIII does not. However, no binding of RANKL to VWF was observed when immobilized-VWF sensor chip was used in contrast to OPG [68]. Overall, the data suggests that the tridimensional structure of the FVIII-VWF complex is mandatory for its interaction with RANKL in contrast to OPG which interacts with the complex via the VWF. In this context, FVIII may contribute to the control of bone remodeling by regulating the interactions of FVIII-VWF complex to RANKL and consequently the biological activities of RANKL (Figure 1).

More recently, the bone phenotype of FVIII-, FIX or VWF-knockout mice has been studied [70-72]. $\mathrm{FVIII}^{-/-}$and $\mathrm{FIX}^{-{ }_{-}}$but not $\mathrm{VWF}^{-{ }_{-}}$male mice develop an osteoporotic phenotype in the absence of induced hemarthrosis or clinically detectable bleeding [72]. This phenotype was exacerbated after joint bleeding induced by injury in $\mathrm{FVIII}^{-/-}$male mice whereas VWF-/did not display the same characteristics, demonstrating that FVIII is involved in the regulation of bone remodeling after injury in contrast to an intact FVIII/VWF complex which is not required for bone remodeling post-injury [72,73]. A direct role for FVIII in osteoblast 
development is suspected [74]. Interestingly, Weitzmann et al. observed sexual dimorphism in the mechanism driving bone loss in $\mathrm{FVIII}^{-/-}$mice [75]. Whether $\mathrm{FVIII}^{-/-}$males and females showed osteoporotic phenotype, bone loss was directly related to a decrease in bone formation in males and an increase in bone resorption in females [76]. These data may potentially be related to a crucial role played by thrombin generation and signaling for the maintenance of a normal bone phenotype. Indeed, thrombin is activated during the coagulation cascade and the bone phenotype observed in FVIII deficient mice may be related to a complete absence of thrombin formation and of thrombin receptor activation.

Protease-activated receptors (PARs) belong to family composed by 4 members that mediate cellular responses to extracellular proteases [77]. Osteoblast precursors (bone marrow stromal cells), osteoblasts and osteoclast precursors express PAR-1 and PAR-2. Thrombin modulates osteoblast activities through activation of the PAR-1 signaling pathway $[78,79]$. Bone structural abnormalities appeared similar in mice with a complete knockout of either FVIII or PAR-1 [79]. However, the contribution of the thrombin/PAR-1 couple in bone biology remains controversial. Tudpor et al. studied the phenotypic impact of thrombin receptor deficiency in mice and revealed increased bone mass in knockout mice, explained by a decreasing RANKL/OPG ratio [79]. Cortical bone volume, as well as trabecular thickness and connectivity, were increased in males but not in females. In contrast, by using the $\alpha$ prothrombin siRNA approach in mice, Taylor et al. did not observe any modification to the bone morphometric parameters in treated mice and concluded that thrombin deficiency was not involved in the mechanism of decreased BMD in HA [80]. In the process of thrombin generation, FXa is generated that may activate PAR-2 expressed in bone cells [77]. PAR-2 ${ }^{-/}$ mice were characterized by a mild osteopetrosis phenotype in the growing mice. The higher cortical and trabecular bone mass with lower osteoblastic and osteoclastic parameters gave 
evidence of the implication of PAR-2 in bone turnover but can not be related to the bone phenotype observed in HA mice [72,81]. The recent use of dabigatran etexilate, a direct thrombin inhibitor, revealed a slight increase in $\mathrm{BMD}$ in $\mathrm{C} 57 \mathrm{BL} / 6$ female mice in contrast to males, in whom no significant difference was observed [82]. Thrombin (e.g. dabigatran) and FXa (e.g. Apixaban, Rivaroxaban) inhibitors have also been assessed in patients regards to the risk of osteoporosis and compared to warfarin, a vitamin $\mathrm{K}$ antagonist [83]. Compared with warfarin, thrombin and FXa inhibitors were associated with a lower of osteoporosis in women but not in men. This observation was in agreement with in vitro observation in which rivaroxaban inhibited the stimulatory effects of bone-modulating hormones (e.g. estrogen) in both primary osteoblasts isolated from premenopausal and postmenopausal women [84]. In addition, compared to dabigatran, thrombin and FXa inhibitors were associated with a lower risk of osteoporosis [85].

Whether there is no ambiguity of the functional impact of FVIII on bone remodeling as demonstrated by the bone phenotype observed in pre-clinical models as well as in HA patients, its mechanisms of action remain controversial. Whether the interactions of FVIII to RANKL through the FVIII-VWF complex could directly influence the osteoclast differentiation and bone resorption, the indirect activity of FVIII on bone remodeling through the regulation of thrombin generation can not be excluded as illustrated by the similar bone Interestingly, as demonstrated in deficient mice, the impact of the FVIII in bone biology is related to functional sexual dimorphism (bone loss directly related to a decrease in bone formation in males and an increase in bone resorption in females) that may be related to nonhemostatic activities. The indirect and/or direct mechanisms of FVIII in bone metabolism need to be better explored. Complementary investigations comparing the impact of 
substitutive and non-substitutive therapies on FVIII deficiency associated bone phenotype are mandatory to definitely respond to the controversy.

\section{Can the polarization of macrophages, the neovascularization and the inflammatory} process be related to the activities of FVIII?

The immune status of HA patients differs from that of healthy donors and is characterized by a prominent pro-inflammatory profile [78]. Macrophages are major cell mediators in the inflammatory process associated with HA hemarthrosis. Their polarization is altered in $\mathrm{FVIII}^{-}$ /- mice [86] and to our knowledge no similar study was carried out in FIX $^{-/}$mice. In a physiological context after their extravasation from blood, monocytes differentiate into M1 and/or M2 macrophage subtypes depending on the microenvironment. In the presence of T helper cells (Th)-1 cytokines such as Interferon (IFN)- $\gamma$, TNF- $\alpha$, or bacterial lipopolysaccharides (LPS), monocytes differentiate into pro-inflammatory M1 macrophages. These macrophages then secrete a large amount of pro-inflammatory cytokines, such as interleukin (IL)-1 $\beta$, IL-6, IL-12, IL-23 or TNF- $\alpha$. M1 macrophages intervene in the elimination of pathogens by generating Reactive Oxygen Species (ROS), antigen presentation or promoting the response of Th1 and Th17 lymphocytes [87]. In the presence of interleukins IL-10, IL-4, IL-13 or Transforming Growth Factor (TGF)- $\beta$, monocytes polarize into type M2 subtype, anti-inflammatory macrophages. M2 macrophages are conventionally classified into 4 types: i) M2a, which plays a key role in tissue remodeling and wound healing, ii) M2b, with an immunoregulatory function by activating regulatory $\mathrm{T}$ cells and $\mathrm{Th} 2$ lymphocytes, iii) M2c, involved in the phagocytosis of apoptotic bodies, and iv) M2d, with pro-angiogenic activities [87]. Transient modifications of monocyte/macrophage populations were observed in $\mathrm{FVIII}^{-/-}$mice after joint injury [86]. These authors observed an increase in M1 monocytes in circulating blood, and a decrease in spleen, combined with a decrease in the M2 subtype in 
the spleen. In addition, a concomitant increase in M1 and M2 macrophages was detectable in synovial tissue post-injury. In contrast, no modification in macrophage polarization was observed in healthy joints [86]. Similarly, a recent study in HA patients also shows deregulation of macrophage polarization [88] (Figure 1). The differentiation properties of purified monocytes isolated from HA patients and healthy donors were compared. Monocytes from HA patients were characterized by a lower rate of polarization compared to cells isolated from healthy donors, with polarization dysregulated in response to Macrophage Colony Stimulating-Factor (M-CSF) (M2 macrophages), and partially dysregulated in response to Granulocyte Colony Stimulating-Factor (GM-CSF) (M1 macrophages). Monocytes from HA patients expressed a lower number of M-CSF and GM-CSF receptors compared to healthy donors. This study supports the biological function of coagulation factors in macrophage polarization. However, hemophilia A and B patients were studied without any distinction and with inadequate control groups making it difficult to raise a clear conclusion on FVIII function in macrophage differentiation. Kist-Toth et al. compared the effects of recombinant FVIII and FVIII-Fc on human macrophages but did not observe any regulation of macrophage polarization in the presence of FVIII [89]. Similar results were obtained on monocyte-derived dendritic cells [90].

Joint bleeding in $\mathrm{FVIII}^{-/}$mice led to synovial neovascularization, characterized by large vessels with high $\alpha$-Smooth Muscle Actin (SMA) expression [91]. Similar neovascularization was observed in $\mathrm{FIX}^{-/-}$mice in cutaneous wound site [92]. Inflammation and macrophage polarization cannot be dissociated in HA. Proinflammatory M1 macrophage infiltration was observed concomitantly with neovessels, followed by a M2 macrophage response contributing to tissue-reparative actions. Overall, an inflammatory reaction was detectable in close soft tissues at the same time as an increase in permeability, and the formation of new 
vessels that promotes re-bleeding (Figure 1). These marked tissue modifications were not prevented by short term FVIII replacement [93]. The localization of recombinant FVIII administered in $\mathrm{FVIII}^{-/}$mice has recently been studied [94]. Recombinant FVIII was preferentially observed in the marginal zone of the spleen with no major co-localization of murine VWF with recombinant human FVIII. Macrophage markers, including the scavenger receptor Macrophage-Associated Receptor with Collagenous structure (MARCO), Sialic acidbinding-Ig-like Lectin-1 (SIGLEC-1) and Specific Intercellular adhesion molecule-3Grabbing Nonintegrin-Related 1 C-type lectin (SIGNR1) were co-localized with infused FVIII [91]. Interestingly, a proinflammatory transcriptional profile was observed in the spleen and liver after administration of recombinant FVIII compared to the vehicle. A series of 33 and 12 upmodulated genes was identified in the spleen and liver respectively, $3 \mathrm{~h}$ after FVIII infusion [91]. These investigations reveal macrophages as a potential target of FVIII.

FVIII may indirectly regulate macrophage activation with functional impact in inflammation and bone tissue. By modulating thrombin and FXa generation as well as downstream signaling associated with PARs, FVIII may modulate the activation of macrophages and potentially bone remodeling. Indeed, the literature is rich in manuscripts describing the contribution of PAR-2 in inflammation in various organs as demonstrated by the use of FXa inhibitors [95-100]. The binding of FXa to PAR-2 induced ERK1/2 signaling and led in the expression of pro-inflammatory cytokines (e.g. IL-6, IL-8, TNF- $\alpha$, IFN- $\gamma$ ) and the differentiation of macrophages toward pro-inflammatory M1 subtype [101,103]. However, the literature remains nuanced and PAR2-mediated M2 skewing has also been reported in response to Mycobacterium tuberculosis antigen [104]. By regulating the differentiation and activation of macrophages which are functionally related to bone remodeling, FXa and indirectly FVIII might be involved in bone diseases [105] (Figure 1). Questions regarding the 
direct or indirect impact of FVIII and the molecular complexes related to FVIII in macrophage differentiation and their role in osteoimmunology remain open and will require new clinical investigations including adequate control groups.

The molecular partners of FVIII: what may be their relationship with the FVIIIassociated inflammation and bone remodeling?

Although VWF was the first partner of FVIII to be described, several membrane receptors controlling the bioavailability of FVIII have been identified more recently. Most FVIII is probably eliminated in a VWF-dependent manner. However, the clearance mechanisms of inactivated FVIII, degraded subunits, or the FVIII-VWF complex have only been partially characterized [106]. Animal studies using radiolabeled FVIII show that the liver and spleen are the major sites for clearance of the FVIII-VWF complex, as well as macrophages $[107,108]$. Scavenger receptors belong to a large family of transmembrane proteins which are expressed predominantly by myeloid cells. These receptors show a high structural diversity and recognize numerous ligands (e.g. soluble proteins, microbial pathogens) [109]. They are involved in a wide range of biological functions including sensing, internalization and degradation of ligands. During the last two decades, various scavenger receptors involved in the clearance of FVIII have been described and may contribute to the biological function of FVIII in inflammation and musculoskeletal tissues (Figure 2).

\section{Low density lipoprotein receptor - related protein 1 (LRP-1)}

LRP-1 is a member of the Low Density Lipoprotein Receptor (LDLR) family which recognizes numerous ligands. It is an endocytic receptor abundantly expressed in the liver, mainly in resident hepatocytes and macrophages [110]. The property of LRP-1 to bind FVIII was initially reported by Saenko et al. [111] and Lenting et al. [112]. Their studies show a 
direct interaction between FVIII and LRP-1 which was reduced by the excess of VWF. LRP-1 appeared to be the major hepatic receptor responsible for clearance of FVIII. Cells expressing LRP-1 were able to internalize radiolabeled FVIII unlike LRP1-deficient cells. Furthermore, the internalization of FVIII by LRP-1 was inhibited by $70 \%$ in the presence of the ReceptorAssociated Protein (RAP) that prevented the binding of FVIII to LRP-1 [113,114]. The internalization of the radiolabeled FVIII-VWF complex was also made possible by LRP-1 and appeared to be promoted by the presence of heparan sulfate proteoglycans (HSPG) expressed at the membrane surface. Simultaneous inhibition of HSPG and LRP-1 results in a longer half-life for FVIII than inhibition of LRP-1 alone [115]. In 2003, Bovenschen et al. confirmed the importance of the LRP-1 receptor in the clearance of FVIII by using a genetically modified mouse model in which LRP-1 was deleted specifically from the liver [116]. This deletion led to doubling of the FVIII plasma concentration, a significant delay in its clearance, and an increased half-life. LRP-1 cooperates with the LDL receptor in the regulation of FVIII plasma levels, as demonstrated in the LDL receptor and LRP-1 double deficient mice [117]. LRP consists of five common structural domains: i) ligand-binding cysteine-rich repeats, ii) epidermal growth factor (EGF) receptor-like cysteine-rich repeats, iii) YWTD domains, iv) a single membrane-spanning segment, v) a cytoplasmic tail (Figure 2). The Ligand-bindingtype repeats occur in clusters containing between two and eleven individual repeats. LRP-1 contains 4 clusters. Surface plasmon resonance experiments revealed that FVIIIa bound clusters I, II of LRP-1. Similarly to LRP chaperone, $\alpha 2$ macrogobulin receptor and Receptor Associated Protein (RAP), FVIIIa LRP-1 also binds cluster III [118]. Finaly, Young et al. identified cluster IV as the major LRP1 binding site for FVIII [117]. LRP-1 contributes to the bone biology by controlling the dialog between osteoblasts and osteoclasts [118,119]. Indeed, LRP-1 is a mitogenic effector in osteoblasts which in turn control osteoclast activity [118120]. In this context LRP-1 protects against osteoporosis [119]. LRP-1 expressed is also 
expressed by young macrophages and depleting Lrpl in macrophages abrogates the benefit effects of macrophage in bone repair [121]. In contrast, the treatment of old mice with recombinant LRP-1 improves fracture healing confirming the crucial role of LRP-1 in bone remodeling and the contribution of macrophages in LRP-1 functions. Consequently, FVIII may act as bone regulator factor by regulating LRP-1 expression at the cell membrane and its internalization [122].

\section{Asialoglycoprotein receptor (ASGPR)}

ASGPR is a member of the C-type (i.e. calcium-dependent) lectin family, abundantly expressed in hepatocytes as well as in macrophages, and involved in binding and endocytosis of glycoproteins in the bloodstream. In 2005, Bovenschen et al. showed that the B domain of FVIII recognized ASGPR in a dose-dependent manner and with high affinity $(\mathrm{Kd} \approx 2 \mathrm{nM})$ [123]. Enzyme treatment with endoglycosidase F completely abolished the interactions between FVIII and ASGPR, showing that the N-glycosylations of FVIII were responsible for their interaction. The half-life of FVIII in the bloodstream increased in the presence of asialoorosomucoid (an ASGPR antagonist) whereas the half-life of B domain-deleted FVIII is comparable to the native FVIII in treated HA patients. However, the physiological significance of this interaction remains unknown. It has been hypothesized that ASGPR may play a role in quality control of secreted FVIII by internalization of the FVIII incompletely Nglycosylated [124]. ASGPR also mediate the clearance of VWF and ASGPR-1 knockout mice had a reduced bleeding time compared to WT littermates in contrast to ASGPR-2 [125]. The control of VWF bioavailability may impact FVIII level and its interaction with bone related factor [67-69]. Valladeau et al. showed the ASPGRs expression by immature dendritic cells which were localized to early endosome highlighting their potential function in the receptor recycling following internalization ligand [126]. The control of FVIII and VWF 
bioavailability as well as the recycling of specific receptors in phagocytic cell types and endothelial cells may regulate the extrahemostatic activities of FVIII. Complementary investigations are required to study the possible impact of ASPGR in bone tissue and to better understand its impact in immune cells.

\section{Sialic acid binding immunoglobulin-like lectin-5 (Siglec-5)}

Siglec-5 belongs to a large family of receptors composed of 14 members with specific affinity to different types of sialic acid structures and conformations. They are mostly expressed by cells of hematopoietic origin, such as neutrophils, B lymphocytes, monocytes, dendritic cells, and macrophages with specific distribution for each member [127]. Siglec-5 is expressed by monocytes/macrophages (including lines such as THP-1 and U937), neutrophils and B cells. VWF and FVIII bind to recombinant Siglec-5 as well as to Siglec-5 expressing cells in vitro [128]. Treating VWF with sialidase resulted in a complete loss of the interaction between VWF and Siglec-5, suggesting that their interaction was dependent on sialic acid. Conversely, this treatment did not affect the interaction between FVIII and Siglec-5. The co-localization of VWF, FVIII and Siglec-5 with endosomal markers suggested that their interaction was followed by their endocytosis [128]. Finally, these authors observed a significant decrease in FVIII-VWF levels in mice overexpressing Siglec-5 in their hepatocytes. Siglec-5 was involved in the control of inflammation [129]. Indeed, Siglec-5 displays anti-inflammatory activity by inhibiting leukocyte-rolling over E- and P-selectins and reduces the basal leukocyte rolling in vivo. In addition, Siglec-5 prevents leukocyte recruitment in a TNF $\alpha$ induced inflammation mode and then displays anti-inflammatory activity. Overall, these results suggest that Siglec-5 may contribute to the regulation of the plasma levels of VWF, FVIII or/and FVIII-VWF complex. The potential functional relationship between FVIII, VWF and Siglec-5 in bone remodeling and inflammatory process must be investigated. 
Stabilin-2 (STAB-2)

STAB-2 is a scavenger receptor member belonging to the C-type lectin family. STAB-2 is expressed by sinusoidal endothelial cells of the liver (LSEC) and spleen, as well as by immune cells such as macrophages. It is a clearance receptor for glycosaminoglycans such as hyaluronic acid [130]. A mutated form of the STAB-2 receptor that affects its expression level was associated with an approximately $30 \%$ increase in FVIII and VWF in plasma, suggesting that STAB-2 was involved in regulating these proteins [130]. STAB-2 may modulate clearance of FVIII in a VWF-dependent manner. The affinity of STAB-2 to FVIII is relatively low in the absence of VWF [131]. STAB-2 contributes to the internalization of VWF as well as that of the FVIII-VWF complex [117]. STAB-2 is highly expressed in bone marrow, lymphoid organs [132,133] and can be expressed by bone derived cancer cells [134]. In contrast to STAB-1 which reduces bone resorption activity in vitro, no data are currently available of the role of the contribution of STAB-2 in bone remodeling [135]. STAB-2 contributes to the clearance of apoptotic cells [136] and FVIII/VWF complex blocks the inhibitory effect of OPG on TNF Related Apoptosis Inducing Ligand (TRAIL) on osteoblastlike cells [68]. Stabilin-2 is involved in lymphocyte adhesion to endothelial cells and by this way could contribute to the inflammation [136]. The functional link between STAB-2 and FVIII in the control of cell apoptosis and leukocyte recruitment/activation remains undetermined.

\section{C-type lectin domain family 4 member M (CLEC4M)}

CLEC4M is a member of the type-C lectin family that encodes L-SIGN (CD299) expressed by sinusoidal endothelial cells of the liver and lymphoid tissues [137]. CLEC4M binds ICAM-3 and HIV gp120. CLEC4M also binds to N-glycan residues of VWF and then 
controls its internalization and clearance [138]. In addition, FVIII binds to CLEC4M by its mannose-exposed N-linked glycans through VWF-dependent and independent mechanisms. FVIII also binds CLEC4M-expressing human embryonic kidney (HEK) 293 cells and is internalized via a clathrin-coated pit-dependent mechanism leading to its catabolism by lysosomes [139]. Unfortunately, there is no study yet available analyzing the expression/function of CLEC4M in bone cells. Its role in the control of inflammatory process is suspected by its ability to bind to SARS-CoV-2 spike protein [140].

\section{Scavenger Receptor Class A Member 5 (SCARA-5)}

The Genome-Wide Association Studies (GWAS) investigation identified the scavenger receptor SCARA-5 as being associated with plasma VWF and/or FVIII [141]. SCARA-5 is a type II membrane protein that contains an extracellular spacer domain, a collagenous domain and a scavenger receptor cysteine rich (SRCR) domain at the $\mathrm{N}$-terminus, and a transmembrane domain. There is also a C-terminus intracellular region. Forming a trimer at the cell surface, SCARA-5 is expressed by a large pattern of tissues including the spleen, heart, and brain. It is expressed by splenic sinusoidal endothelial cells and plasmocytoid dendritic cells. SCARA-5 was co-localized with VWF and can bind and internalize this factor alone or in a complex with FVIII. The binding and internalization of FVIII to SCARA-5 cannot occur in the absence of VWF [142]. SCARA-5 is expressed by osteoblastic like cells and inhibits their proliferation [143]. SCARA-5 contributes to adipogenesis by facilitating the commitment of mesenchymal stem cells toward adipocyte [144]. Interestingly, a dysregulation of the balance adipogenesis and osteoblastogenesis in favor of adipogenesis led to a decreased bone mineral density in osteoporotic patients [145]. Overall, these data support a potential involvement of SCARA-5 in which FVIII may be associated. 


\section{Conclusions}

Joint bleedings lead to local inflammation, immune cell recruitment and the differentiation of macrophages as observed in HA patients. Neither the preclinical mouse models used nor the clinical-biological investigations allow to exclude the role of the generation of thronmbin in the biological effects observed. Various studies described bone pehnotype and aleration of macrophage polarization in HA patients. Unfortunately, most of these investigations carried out did not include the adequate control making difficult to assign a definitive direct role of FVIII idependently of its hemostatic activities. The biological activities of FVII independently of the thrombin/thrombin receptor axis remains controversed but may be explained by its interaction with numerous protein partners. It can be speculated that the effect of FVIII on bone may be associated to the regulation of RANKL/OPG axis with a major impact on osteosclastogenis and bone resoprtion. Similarly complementary studies are needed to investigate the regulation this functional relationship in vascular and immune system as RANKL/OPG regulate endothelial cells as well as the recruitment of macrophages [65]. FVIII is cleared via macrophages/endothelial cells and macrophage/endothelial-specific receptors and there is not current evidence that these interactions affect macrophage/endothelial status. However, the functional impact of the interactions between FVII and these receptors must be remained open to the investigation without dogmatic position.

The treatments used in HA have hitherto been based on supplying the FVIII missing from plasma in either its original or recombinant form [147]. Severe hemophiliacs with a FVIII level of less than $1 \%$ can benefit from prophylactic treatment for FVIII to limit the occurrence of hematomas and hemarthrosis and to preserve their joints. Alternative therapies are available, in particular Emicizumab. Emicizumab is a bispecific antibody mimicking the hemostatic activity of FVIII that is available as a prophylactic treatment for severe HA 
patients as a replacement for exogenous FVIII [146-148]. This molecule mimics the ability of FVIII to bring activated factor IX in proximity to coagulation factor $\mathrm{X}$ to catalyze the proteolytic generation of activated factor $\mathrm{X}$ and continue the coagulation cascade. Other molecules are also being tested in the treatment of hemophilia, by inhibiting coagulation inhibitors [inhibitor of anti-tissue factor pathways (TFPI), antithrombin inhibitors] in order to restore the hemostatic balance to a static balance. Such approaches can be used in patients with severe hemophilia, and they are interesting tools in the therapeutic arsenal for treating hemophilia. However, it is unknown whether they can restore the non-hemostatic functions of FVIII or whether they may have indirect adverse effects in the long term. Clinical trials are mandatory for comparing both therapeutic approaches, and better understanding the extrahemostatic functions of FVIII is a prerequisite.

\section{Additional information}

\section{Competing interests}

- Prof. D. Heymann has received research support from Baxter/Baxalta (now a part of Shire)

- Prof. P.E. Monahan holds patents licensed to Asklepios, for which he receives royalties. He has received payment for consultation, services, and for speaking for Asklepios, Chatham LLC, Baxter Healthcare and Pfizer and has additionally consulted for Bayer, Novo Nordisk, and Biogen. He is now an employee of Spark Therapeutics.

\section{References}

[1] Carcao, M.D. (2012). The diagnosis and management of congenital hemophilia. Seminar in Thrombosis and Hemostasis, 38, 727-34.

[2] Mannucci, P.M., \& Tuddenham, E,G. (2001). The hemophilias- from royal genes to gene therapy. The New England Journal of Medicine 344, 17773-79. 
[3] Song, M.J., Kim, H.J., Yoo, K.Y. et al., (2011). Molecular characterization of female hemophilia A by multiplex ligation-dependent probe amplification analysis and $\mathrm{X}$ chromosome inactivation study. Blood Coagulation \& Fibrinolysis 22, 211-14

[4] Lenting, P.J., van Mourik, J.A. \& Mertens, K. (1998). The life cycle of coagulation factor VIII in view of its structure and function. Blood 11,3983-3996

[5] Mertens, K. \& Bertina, R.M. (1982). Activation of human coagulation factor VIII by activated factor $\mathrm{X}$, the common product of the intrinsic and the extrinsic pathway of blood coagulation. Thrombosis and Haemostasis 2,96-100.

[6] Kamikubo, Y., Mendolicchio, G.L., Zampolli, A., Marchese, P. et al. (2017). Rothmeier AS, Orje JN, et al. Selective factor VIII activation by the tissue factor-factor VIIa-factor Xa complex. Blood 14, 1661-1670.

[7] Sang, Y., Roest, M., de Laat, B., de Groot, P.G. et al. Interplay between platelets and coagulation. Blood Reviews 2020; (in press).

[8] Pipe, S.W., Montgomery, R.R., Pratt, K.P., Lenting, P.J. et al. (2016). Life in the shadow of a dominant partner: the FVIII-VWF association and its clinical implications for hemophilia A. Blood 16,2007-2016.

[9] Valentino, L.A. \& Khair, K. (2020). Prophylaxis for hemophilia A without inhibitors: treatment options and considerations. Expert Review Hematology 13, 731-43.

[10] Peyvandi, F., Garagiola, I. \& Young, G. (2016). The past and future of haemophilia: diagnosis, treatments, and its complications. The Lancet 10040,187-197.

[11] Pool, J.G., Gershgold, E.J. \& Pappenhagen, A.R. (1964). High-potency antihaemophilic factor concentrate prepared from cryiglobukin precipitate. Nature 203,312.

[12] Manco-Johnson, M.J., Abshire, T.C., Shapiro, A.D., Riske, B. et al. (2007). Prophylaxis versus episodic treatment to prevent joint disease in boys with severe hemophilia. The New England Journal of Medicine 6,535-544.

[13] Tiede, A. (2015). Half-life extended factor VIII for the treatment of hemophilia A. journal of thrombosis and haemostasis S176-9.

[14] Powell, J.S., Josephson, N.C., Quon, D., Ragni, M.V. et al. (2012). Cheng G, Li E, et al. Safety and prolonged activity of recombinant factor VIII Fc fusion protein in hemophilia A patients. Blood 119,3031-77.

[15] Powell, J.S., Pasi, K.J., Ragni, M.V., Ozelo, M.C., et al. (2013). Phase 3 study of recombinant factor IX Fc fusion protein in hemophilia B. The New England Journal of Medicine 369, 2313-23.

[16] Seth Chhabra, E., Liu, T., Kulman, J., Patarroyo-White, S. et al. (2020). BIVV001, a new class of factor VIII replacement for hemophilia A that is independent of von Willebrand factor in primates and mice. Blood 135,1484-96. 
[17] Konkle, B.A., Shapiro, A.D., Quon, D.V., Staber, J.M. et al. (2020). BIVV001 Fusion Protein as Factor VIII Replacement Therapy for Hemophilia A. The New England Journal of Medicine 11,1018-1027.

[18] Rangarajan, S., Walsh, L., Lester, W., Perry, D. et al. (2017). AAV5-Factor VIII Gene Transfer in Severe Hemophilia A. The New England Journal of Medicine 377, 2519-30.

[19] Perrin, G.Q., Herzog, R.W. \& Markusic, D.M. (2019). Update on clinical gene therapy for hemophilia. Blood 5, 407-414.

[20] Stanford, S., Pink, R., Creagh, D., Clark, A. et al. (2019). Adenovirus-associated antibodies in UK cohort of hemophilia patients: A seroprevalence study of the presence of adenovirus-associated virus vector-serotypes AAV5 and AAV8 neutralizing activity and antibodies in patients with hemophilia A. Research and Practice in Thrombosis and Haemostasis 2, 261-267.

[21] Peyvandi, F., Mannucci, P.M., Garagiola, I., El-Beshlawy, A. et al. (2016). A Randomized Trial of Factor VIII and Neutralizing Antibodies in Hemophilia A. The New England Journal Medicine 21,2054-2064.

[22] Pratt, K.P., Arruda, V.R. \& Lacroix-Desmazes, S. (2021). Inhibitors-Recent insights. Haemophilia 2021, 28-36.

[23] Marcucci, M., Mancuso, M.E., Santagostino, E. et al. (2015). Type and intensity of FVIII exposure on inhibitor development in PUPs with haemophilia A. A patient-level metaanalysis. Thrombosis \& Haemostasis 5,958-967.

[24] Drillaud, N., Babuty, A., Rugeri, L., Fouassier, M. et al. (2020). Management of previously untreated patients with severe haemophilia A preferentially treated with recombinant factor VIII products: Two French centres' real-life experience. Haemophilia 6, e349-e352.

[25] Kitazawa, T., Igawa, T., Sampei, Z., Muto, A. et al. (2012). A bispecific antibody to factors IXa and X restores factor VIII hemostatic activity in a hemophilia A model. Nature Medicine 18, 1570-74.

[26] Sehgal, A., Barros, S., Ivanciu, L., Cooley, B. et al. (2015). An RNAi therapeutic targeting antithrombin to rebalance the coagulation system and promote hemostasis in hemophilia. Nature Medicine 21, $492-7$.

[27] Chowdary, P. (2020). Anti-tissue factor pathway inhibitor (TFPI) therapy: a novel approach to the treatment of haemophilia. International Journal of Hematology 1, 4250.

[28] Barnes, C., Wong, P., Egan, B., Speller, T. Et al. (2004). Reduced bone density among children with severe hemophilia. Pediatrics 114, e177-81. 
[29] Lee, A., Boyd, S.K., Kline, G. \& Poon, M.C. (2015). Premature changes in trabecular and cortical microarchitecture result in decreased bone strength in hemophilia. Blood $125,2160-63$.

[30] Sossa Melo, C.L., Wandurraga, E.A., Peña, A.M., Jiménez, S.I. et al. (2018). Low bone mineral density and associated factors in patients with haemophilia in Colombia. Haemophilia 24, e222-29.

[31] Soucek, O., Komrska, V., Hlavka, Z., Cinek, O. et al. (2012). Boys with haemophilia have low trabecular bone mineral density and sarcopenia, but normal bone strength at the radius. Haemophilia 18, 222-8.

[32] Abdelrazik, N., Reda, M, El-Ziny, M. \& Rabea, H. (2007). Evaluation of bone mineral density in children with hemophilia: Mansoura University children hospital (MUCH) experience, Mansoura, Egypt. Hematology 12, 431-7.

[33] El-Mikkawy, D.M.E., Elbadawy, M.A., Abd El-Ghany, S.M. \& Samaha, D. (2019). Serum sclerostin level and bone mineral density in pediatric hemophilic arthropathy. Indian Journal of Pediatric 86, 515-9.

[34] Ranta, S., Viljakainen, H., Mäkipernaa, A. \& Mäkitie, O. (2011). Hypercalciuria in children with haemophilia suggests primary skeletal pathology. British Journal of Haematology 153,364-71.

[35] Christoforidis, A., Economou, M., Papadopoulou, E., Kazantzidou, E. Et al. (2010). Bone status of children with hemophilia A assessed with quantitative ultrasound sonography (QUS) and dual energy X-ray absorptiometry (DXA). Journal Pediatric Hematology Oncology 32, e259-63.

[36] Anagnostis, P., Vakalopoulou, S., Slavakis, A., Charizopoulou, M. et al. (2012). Reduced bone mineral density in patients with haemophilia A and B in Northern Greece. Thrombosis \& Haemostasis 107, 545-51.

[37] Ashritha, A., Delhi Kumar, C.G., Sahoo, J. \& Nalini, P. (2019). Evaluation of bone mineral density in children with hemophilia: an observational case-control study. Journal of Pediatric Hematolology Oncology 41, 511-4.

[38] Naderi, A., Nikvarz, M., Arasteh, M. \& Shokoohi, M. (2012). Osteoporosis/osteopenia and hemophilic arthropathy in severe hemophilic patients. Archives of Iranian Medicine $15,82-4$.

[39] Roushan, N., Meysamie, A., Managhchi, M. \& Esmaili, J. (2014). Dormohammadi T. Bone mineral density in hemophilia patients. Indian Journal of Hematology and Blood Transfusion 230,351-5.

[40] Mansouritorghabeh, H., Rezaieyazdi, Z., Saadati, N., Saghafi, M. et al. (2009). Reduced bone density in individuals with severe hemophilia B. International Journal of rheumatic Diseases 12, 125-9. 
[41] Falk, B., Portal, S., Tiktinsky, R., Zigel, L. et al. (2005). Bone properties and muscle strength of young haemophilia patients. Haemophilia 11,380-6.

[42] Ulivieri, F.M., Rebagliati, G.A.A., Piodi, L.P., Solimeno, L.P. et al. (2018). Usefulness of bone microarchitectural and geometric DXA-derived parameters in haemophilic patients. Haemophilia 24,980-7.

[43] Linari, S., Montorzi, G., Bartolozzi, D., Borderi, M. et al. (2013). Hypovitaminosis D and osteopenia/osteoporosis in a haemophilia population: a study in HCV/HIV or HCV infected patients. Haemophilia 19,126-33.

[44] Tiacuilo-Parra, A., Villela-Rodríguez, J., Garibaldi-Covarrubias, R., Soto-Padilla, J. Et al. (2011). Bone turnover markers and bone mineral density in children with haemophilia. Haemophilia 17,657-61.

[45] Khawaji, M., Akesson, K., Berntorp, E. (2009). Long-term prophylaxis in severe haemophilia seems to preserve bone mineral density. Haemophilia 15,261-6.

[46] Khawaji, M., Astermark, J., Von Mackensen, S., Akesson, K., et al. (2011). Bone density and health-related quality of life in adult patients with severe haemophilia. Haemophilia 17,304-11.

[47] Ekinci, O., Demircioglu, S., Dogan, A., Merter, M. et al. (2019). Decreased bone mineral density and associated factors in severe haemophilia A patients: A case-control study. Haemophilia 25,e315-21.

[48] Sahin, S., Sadri, S., Baslar, Z. \& Cem Ar, M. (2019). Osteoporosis in patients with hemophilia: single-center results from a middle-income country. Clinical and Applied Thrombosis/Hemostasis 25, 1076029619861689.

[49] Culha, V., Akpinar Tekgündüz, S., Yarali, H.N. et al. (2019). Impact of prophylaxis on bone mineral metabolism in children with hemophilia. Journal of Pediatric Hematology Oncology 41,121-3.

[50] Dagli, M., Kutlucan, A., Abusoglu, S., Basturk, A. Et al. (2018). Evaluation of bone mineral density (BMD) and indicators of bone turnover in patients with hemophilia. Bosnian Journal of Basic Medical Sciences 18, 206-210.

[51] Kiper Unal, H.D., Comert Ozkan, M., Atilla, F.D., Demirci, Z. et al. (2017).Evaluation of bone mineral density and related parameters in patients with haemophilia: a single center cross-sectional study. American Journal of Blood Research 27, 59-66.

[52] Alioglu, B., Selver, B., Ozsoy, H., Koca, G., et al (2015). Evaluation of bone mineral density in Turkish children with severe haemophilia A: Ankara hospital experience. Haemophilia 18, 69-74.

[53] Wells, A.J., McLaughlin, P., Simmonds, J.V., Prouse, P.J. et al. (2015). A case-control study assessing bone mineral density in severe haemophilia A in the UK. Haemophilia 21,109-15. 
[54] Gay, N.D., Lee, S.C., Liel, M.S., Sochacki, P. et al. (2015). Increased fracture rates in people with haemophilia: a 10-year single institution retrospective analysis. British Journal of Haemotology 170,584-6.

[55] Kempton, C.L., Antun, A., Antoniucci, D.M., Carpenter, W. et al. (2014). Bone density in haemophilia: a single institutional cross-sectional study. Haemophilia 20,121-8.

[56] Gerstner, G., Damiano, M.L., Tom, A., Worman, C. et al. (2009). Prevalence and risk factors associated with decreased bone mineral density in patients with haemophilia. Haemophilia 15, 559-65.

[57] Rodriguez-Merchan, E.C. \& Valentino, L.A. (2019). Increased bone resorption in hemophilia. Blood Reviews 33, 6-10.

[58] Goldscheitter, G., Recht, M., Sochacki, P., Manco-Johnson, M. et al. (2021). Biomarkers of bone disease in persons with hemophilia. Haemophilia 27,149-155.

[59] Gerstner, G., Damiano, M.L., Tom, A., Worman, C. et al. (2009). Prevalence and risk factors associated with decreased bone mineral density in patients with haemophilia. Haemophilia 15, 559-65

[60] Gay, N.D., Lee, S.C., Liel, M.S., Sochacki, P. et al.(2015). Increased fracture rates in people with haemophilia: a 10-year single institution retrospective analysis. British Journal of Haematology 170,584-6.

[61] Caviglia, H., Landro, M.E., Galatro, G., Candela, M. et al. (2015). Epidemiology of fractures in patients with haemophilia. Injury 46,1885-90.

[62] Khawaji M, Akesson K, Berntorp E. Long-term prophylaxis in severe haemophilia seems to preserve bone mineral density. Haemophilia 2009; 15:261-6.

[63] Andrawes, N.G., Fayek, N.H., El-dihn, N.S. \& Mostafa, R.A. (2020). Effect of low-dose factor VIII prophylaxis therapy on bone mineral density and $25(\mathrm{OH})$ vitamin D level in children with severe haemophilia A. Haemophilia 26,325-32.

[64] Benslimane-Ahmin, Z., Heymann, D., Dizier, B., Lokajczyk, A. et al. (2011). Osteoprotegerin, a new actor in vasculogenesis, stimulates endothelial colony-forming cells properties. Journal of Thrombosis \& Haemostasis 9,834-43.

[65] Baud'huin, M., Lamoureux, F., Duplomb, L., Rédini, F. et al. (2007). RANKL, RANK, osteoprotegerin: key partners of osteoimmunology and vascular diseases. Cellular \& Molecular Life Science 64,2334-50.

[66] Baud'huin, M., Duplomb, L., Teletchea, S., Lamoureux, F. et al. (2013). Osteoprotegerin: multiple partners for multiple functions. Cytokine Growth Factor Reviews 2013; 24:401-9.

[67] Zannettino, A.C., Holding, C.A., Diamond, P., Atkins, G.J. et al. (2005). Osteoprotegerin (OPG) is localized to the Weibel-Palade bodies of human vascular endothelial cells and 
is physically associated with von Willebrand factor. Journal of Cellular Physiology 204, $714-23$

[68] Baud'huin, M., Duplomb, L., Téletchéa, S., Charrier, C. et al. (2009). Factor VIII-von Willebrand factor complex inhibits osteoclastogenesis and controls cell survival. Journal of Biological Chemistry 284,31704-13.

[69] Shahbazi, S., Lenting, P.J., Fribourg, C., Terraube, V. et al. (2007). Characterization of the interaction between von Willbrand factor and osteoprotegerin. Journal of Thrombosis \& Haemostasis 5,1956-62.

[70] Liel, M.S., Greenberg, D.L., Recht, M., Vanek, C., Klein, R.F. et al. (2012). Decreased bone density and bone strength in a mouse model of severe factor VIII deficiency. British Journal of Haematology 158,140-3.

[71] Recht, M., Liel, M.S., Turner, R.T., Klein, R.F. et al. (2013). The bone disease associated with factor VIII deficiency in mice is secondary to increased bone resorption. Haemophilia 19,908-12.

[72] Taves, S., Sun, J., Livingston, E.W., Chen, X. et al. (2019). Hemophilia A and B mice, but not $\mathrm{VWF}^{-/}$mice, display bone defects in congenital development and remodeling after injury. Scientific Reports 9,14428.

[73] Lau, A.G., Sun, J., Hannah, W.B., Livingston, E.W. et al. (2014). Joint bleeding in factor VIII deficient mice causes an acute loss of trabecular bone and calcification of joint soft tissues which is prevented with aggressive factor replacement. Haemophilia 20,716-22.

[74] Larson, E. \& Taylor, J.A. (2017). Factor VIII plays a direct role in osteoblast development. Blood 130, 3661.

[75] Weitzmann, M.N., Roser-Page, S., Vikulina, T., Weiss, D. et al. (2019). Reduced bone formation in males and increased bone resorption in females drive bone loss in hemophilia A mice. Blood Advances 3, 288-300.

[76]. Mackie, E.J., Loh, L.H., Sivagurunathan, S., Uaesoontrachoon, K. et al. (2008). Protease-activated receptors in the musculoskeletal system. International Journal of Biochemestry \& Cell Biology 40,1169-84.

[77] Pagel, C.N., Song, S.J., Loh, L.H., Tudor, E.M. et al. (2009). Thrombin-stimulated growth factor and cytokine expression in osteoblasts is mediated by protease-activated receptor-1 and prostanoids. Bone 44, 813-21.

[78] Aronovich, A., Nur, Y., Shezen, E., Rosen, C. et al. (2013). A novel role for factor VIII and thrombin/PAR1 in regulating hematopoiesis and its interplay with the bone structure. Blood 122, 2562-71.

[79] Tudpor, K., van des Eerden, B.J.C., Jongwattanapisan, P., Roelofs, J.J.T.J. et al. (2015). Thrombin receptor deficiency leads to a high bone mass phenotype by decreasing the RANKL/OPG ratio. Bone 72,14-22. 
[80] Taylor, H.J., Goldscheitter, G. \& Taylor, J.A. (2018). The Role of thrombin deficiency on skeletal health. Blood 132,5012.

[81] Georgy, S.R., Pagel, C.N., Ghasem-Zadeh, A., Zebaze, R.M.D. et al. (2012). Proteinaseactivated receptor-2 is required for normal osteoblast and osteoclast differentiation during skeletal growth and repair. Bone 50, 04-12.

[82] Brent, M.B., Thomsen, J.S. \& Bruël, A. (2017). The effect of oral dabigatran etelixate on bone density, strength, and microstructure in healthy mice. Bone Reports 8,9-17.

[83] Huang, H.K., Liu, P.P., Lin, S.M., Hsu, J.Y. et al. (2021). Risk of developing diabetes in patients with atrial fibrillation taking non-vitamin $\mathrm{K}$ antagonist oral anticoagulants or warfarin: A nationwide cohort study. Diabetes Obesity \& Metabolism 23,499-507.

[84] Somjen, D., Sharfman, Z.T., Katzburg, S., Sharon, O. et al. (2017). Rivaroxaban significantly inhibits the stimulatory effects of bone-modulating hormones: In vitro study of primary female osteoblasts. Connect Tissue Research 58,215-20.

[85] Jardim, L.L., Chaves, D.G., Silveira-Cassette, A.C.O., Silva, A.C.S.E. et al. (2017). Immune status of patients with haemophilia A before exposure to factor VIII: first results from the HEMFIL study. British Journal of Heamatololgy 178, 971-8.

[86] Nieuwenhuizen, L., Schugens, R.E.G., Coeveled, K., Mastbergen, S.C. et al. (2014). Roosendaal G, Biesma DH, et al. Hemarthrosis in hemophilic mice results in alterations in M1-M2 monocyte/macrophage polarization. Thrombosis Research 133, 390-5.

[87] Shapouri-Moghaddam, A., Mohammadian, S., Vazini, H., Taghadosi, M. et al. (2018). Macrophage plasticity, polarization, and function in health and disease. Journal of Cellular Physiology 233, 6425-40.

[88] Knowles, L.M., Kagiri, D., Bernard, M., Schwarz, E.C. et al. (2019). Macrophage polarization is deregulated in haemophilia. Thrombosis \& Haemostasis 119, 234-45.

[89] Kis-Toth, K., Rajani, G.M., Simpson, A., Henry, K.L. et al. (2018). Recombinant factor VIII Fc fusion protein drives regulatory macrophage polarization. Blood Advances 2, 2904-16.

[90] Kannicht, C., Danßmann, I., Weilandt, C., Derkow, K. et al. (2020). Factor VIII Fc Fusion Protein but not FVIII Drives Human Monocyte-Derived Dendritic Cell Activation via Fc $\gamma$ RIIa. Hemasphere 4, e330.

[91] Cooke, E.J., Zhou, J.Y., Wyseure, T., Joshi, S. et al. (2018). Vascular permeability and remodelling coincide with inflammatory and reparative processes after joint bleeding in factor VIII-deficient mice. Thrombosis \& Haemostasis 118, 1036-47.

[92] McDonald, A., Hoffman, M., Hedner, U., Roberts, H.R. et al. (2007). Restoring hemostatic thrombin generation at the time of cutaneous wounding does not normalize healing in hemophilia B. Journal of Thrombosis \& Haemostasis 5, 1577-83. 
[93] Cooke, E.J., Wyseure, T., Zhou, J.Y., Gopal, S. et al. (2019). Mechanism of vascular permeability and remodeling associated with hemarthrosis in factor VIII-deficient mice. Journal of Thrombosis \& Haemostasis 17,1815-26.

[94] Lai, J.D., Cartier, D., Hartholt, R.B., Swystun, L.L. et al. (2018). Early cellular interactions and immune transcriptome profiles in human factor VIII-exposed hemophilia A mice. Journal of Thrombosis \& Haemostasisi 16,533-45.

[95] Ding, Y., Li, X., Zhou, M., Cai, L. et al. (2020). Factor Xa inhibitor rivaroxaban suppresses experimental abdominal aortic aneurysm progression via attenuating aortic inflammation. Vascular Pharmacology 21,106818.

[96] Ishikawa, H., Shimada, M., Narita, M., Narita, I. et al. (2019). Rivaroxaban, a direct factor Xa inhibitor, ameliorates hypertensive renal damage through inhibition of the inflammatory response mediated by protease-activated receptor pathway. Journal of American Heart Association 8,e012195.

[97] Shi, M., Wang, L., Zhou, J., Ji, S., Wang, N., et al. (2018). Direct factor Xa inhibition attenuates acute lung injury progression via modulation of the PAR-2/NF-kappaB signaling pathway. American Journal of Translational Research 10,2335-49.

[98] Hara, T., Phuong, P.T., Fukuda, D., Yamaguchi, K. et al. (2018). Protease-activated receptor-2 plays a critical role in vascular inflammation and atherosclerosis in apolipoprotein E-deficient mice. Circulation 138, 1706-19.

[99] Hara, T., Fukuda, D., Tanaka, K., Higashikuni, Y. et al. (2015). Rivaroxaban, a novel oral anticoagulant, attenuates atherosclerotic plaque progression and destabilization in ApoE-deficient mice. Atherosclerosis 242,639-46.

[100] Kelso, E.B., Ferrell, W.R., Lockhart, J.C., Elias-Jones, I. et al. (2007). Expression and proinflammatory role of proteinase-activated receptor 2 in rheumatoid synovium: ex vivo studies using a novel proteinase-activated receptor 2 antagonist. Arthritis \& Rheumatism 56, 765-71.

[101] Zuo, P., Zuo, Z., Wang, X., Chen, L. et al. (2015). Factor Xa induces pro-inflammatory cytokine expression in RAW 264.7 macrophages via protease-activated receptor-2 activation. American Journal of Translational Research 7,2326-34.

[102] Chen, L., Gao, B., Zhang, Y. et al. (2019). PAR2 promotes M1 macrophage polarization and inflammation via FOXO1 pathway. Journal of Cell Biochemistry 120,9799-809.

[103] Husa, C., Ortiz, A.C., Dunning, L., McGavin, L. et al. (2016). Proteinase-activated receptor-2 modulates OA-related pain, cartilage and bone pathology. Annals of the Rheumatic Diseases 75, 1989-97.

[104] Garcia-Gonzalez, G., Sanchez-Gonzalez, A. Hernandez-Bello, R., Gonzalez, G.M. et al. (2019). Triggering of protease-activated receptors (PARs) induces alternative M2 macrophage polarization with impaired plasticity. Molecular Immunology 114, 27888 . 
[105] Toni, R., Di Conza, G., Barbaro, F., Zini, N. et al. (2020). Microtomograpgy of immune cells in osteoporosis and bone lesions by endocrine disruptors. Frontiers in Immunology $11,1737$.

[106] Swystun, L.L., Ogiwara, K., Rawley, O., Brown, C. et al. (2019). Genetic determinants of VWF clearance and FVIII binding modify FVIII pharmacokinetics in pediatric hemophilia A patients. Blood 134, 880-91.

[107] Navarrete, A., Dasgupta, S., Delignat, S. et al. (2009). Splenic marginal zone antigenpresenting cells are critical for the primary allo-immune response to therapeutic factor VIII in hemophilia. Journal of Thrombosis \& Haemostasis 7,1816-23.

[108] Van Schooten, C.J., Shahbazi, S., Groot, E. et al. (2008). Macrophages contribute to the cellular uptake of von Willebrand factor and factor VIII in vivo. Blood 112, 1704-12.

[109] PrabhuDas, M.R., Baldwin, C.L., Bollyky, P.L., Bowdish, D.M.E. et al. (2017). A consensus definitive classification of scavenger receptors and their roles in health and disease. Journal of Immunology 198, 3775-89.

[110] Young, P.A., Migliorini, M. \& Strickland, D.K. (2016). Evidence that factor VIII forms a bivalent complex with the low density lipoprotein (LDL) receptor-related protein 1 (LRP1): identification of cluster IV on LRP1 as the major binding site. Journal of Biological Chemistry 291, 26035-44.

[111] Saenko, E.L., Yakhyaev, A.V., Mikhailenko, I., Strickland, D.K. et al. (1999). Role of the low density lipoprotein-related protein receptor in mediation of factor VIII catabolism. Journal of Biological Chemistry 274,37685-92.

[112] Lenting, P.J., Neels, J.G., van den Berg, B.M., Clijsters, P.P. et al. (1999). The light chain of FVIII comprises a binding site for low density liprotein receptor-related protein. Journal of Biological Chemistry 274, 23734-39.

[113] Sarafanov, A.G., Ananyeva, N.M., Shima, M. \& Saenko, E.L. (2001). Cell surface heparan sulfate proteoglycans participate in facor VIII catabolims mediated by low density lipoprotein receptor-related protein. Journal of Biological Chemistry 276,119709

[114] Bovenschen, N., Herz, J., Grimbergen, J.M., Lenting, P.J. et al. (2003). Elevate plasma factor VIII in a mouse model of low-density lipoprotein receptor-related protein deficiency. Blood 101, 3933-39.

[115] Bovenschen, N., Mertens, K., Hu, L., Havekes, L.M. et al. (2005). LDL receptor cooperates with LDL receptor-related protein in regulating plasma levels of coagulation factor VIII in vivo. Blood 106,906-12.

[116] Kurasawa, J.H., Shestopal, S.A., Woodle, S.A., Mikhail Ovanesov, V., et al (2015). Cluster III of low-density lipoprotein receptor-related protein 1 binds activated blood coagulation factor VIII. Biochemistry 2015, 481-9 
[117] Young, P.A., Migliorini, M. \& Strickland, D.K (2016). Evidence That Factor VIII Forms a Bivalent Complex with the Low Density Lipoprotein (LDL) Receptor-related Protein 1 (LRP1): identification of cluster IV on LRP1 as the major binding site. Journal of Biological Chemistry 291, 26035-44.

[118] Kohara, Y., Haraguchi, R., Kitazawa, R., Kitazawa, S. et al. (2020). Knockdown of Lrp1 in RAW264 cells inhibits osteoclast differentiation and osteoclast-osteoblast interactions in vitro. Biochemical \& Biophysical Research Communications 523,961-5.

[119] Bartelt, A., Behler-Janbeck, F., Beil, F.T., Koehne, T. et al. (2018). Lrp1 in osteoblasts controls osteoclast activity and protects against osteoporosis by limiting PDGFRANKL. Signaling. Bone Research 26,6:4.

[120] Grey, A., Banovic, T., Zhu, Q., Watson, M. et al. (2004). The low-density lipoprotein receptor-related protein 1 is a mitogenic receptor for lactoferrin in osteoblastic cells. Molecular Endocrinology 18,2268-78.

[121] Vi, L., Bath, G.S., Soderblom, E.J., Whetstone, H. et al. (2018). Macrophage cells secrete factors including LRP1 that orchestrate the rejuvenation of bone repair in mice. Nature Communications 9,5191.

[122] Bloem, E., Karpf, D.M., Norby, P.L., Johansen, P.B. et al. (2019). Factor VIII with a 237 amino acid B-domain has an extended half-life in F8-knockout mice. Journal of Thrombosis \& Haemostasis 17,350-60.

[123] Pipe, S.W. (2009). Functional roles of the factor VIII B domain. Haemophilia 15,118796.

[124] Bovenschen, N., Rijken, D.C., Havekes, L.M., van Vlijmen, B.J. et al. (2005). The B domain of coagulation factor VIII interacts with the asialoglycoprotein receptor. Journal of Thrombosis \& Haemostasis 3,1257-65.

[125] Grewal, P.K., Uchiyama, S., Ditto, D., Varki, N. et al. (2008). The Ashwell receptor mitigates the lethal coagulopathy of sepsis. Nature Medicine 14,648-55.

[126] Valladeau, J., Duvert-Frances, V., Pin, J.J., Kleijmeer, M.J. et al. (2001). Immature human dendritic cells express asialoglycoprotein receptor isoforms for efficient receptor-mediated endocytosis. Journal of Immunology 167,5767-74.

[127] Connoly, N.P., Jone, M. \& Watt, S. (2002). Human Siglec-5: tissue distribution, novel isoform and domain specificities for sialic acid-dependent ligand interactions. British Journal of Hematology 119,221-38.

[128] Pegon, J.N., Kurdi, M., Casari, C., Odouard, S. et al. (2012). Factor VIII and von Willebrand factor are ligands for the carbohydrate-receptor Siglec-5. Haematologica 97,1855-63.

[129] Pepin, M., Mezouar, S., Pegon, J., Muczynski, V. et al. (2016). Soluble Siglec-5 associates to PSGL-1 and displays anti-inflammatory activity. Scientific Reports 6,37953 . 
[130] Swystun, L.L., Lai, J.D., Notley, C., Georgescu, I. et al. (2018). The endothelial cell receptor stabilin-2 regulates VWF-FVIII complex half-life and immunogenicity. Journal of Clinical Investigation 128,4057-73.

[131] Huffman, J.E., de Vries, P.S., Morrison, A.C., Sabater-Lleal, M. et al. (2015). Rare and low-frequency variants and their association with plasma levels of fibrinogen, FVII, FVIII, and VWF. Blood 126,e19-29.

[132] Hare, A.K. \& Harris, E.N. (2015). Tissue-specific splice variants of HARE/Stabilin-2 are expressed in bone marrow, lymph node, and spleen. Biochemical \& Biophysical Research Communications 456,257-61.

[133] Park, S.Y., Kim I.S. (2019). Stabilin receptors: role as phosphatidyl serine receptors. Biomolecules 9:387.

[134] Saadaat. R, Abdul-Ghafar, J., Ud Din, N. \& Haidary, A.M. (2020). Anal extraskeletal osteosarcoma in a man: a case report and review of the literature. Journal of Medical Case Reports 14,51

[135] Kim, S.Y., Lee, E.H., Park, S.Y., Choi, H. et al. (2019). Ablation of stabilin-1 enhances bone-resorbing activity in osteoclasts in vitro. Calcif Tissue International 105,205-14.

[136] Jung, M.Y., Park, S.Y. \& Kim, I.S. Stabilin-2 is involved in lymphocyte adhesion to the hepatic sinusoidal endothelium via the interaction with alphaMbeta2 integrin. Journal of Leukocyte Biology 82,1156-65.

[137] Khoo, U.S., Chan, K.Y., Chan, V.S. et al. (2008). DC-SIGN and L-SIGN: the SIGNs for infection. Journal of Molecular Medicine (Berl) 86,861-74.

[138] Rydz, N., Swystun, L.L., Notley, C., Paterson, A.D. et al. (2013). The C-type lectin receptor CLEC4M binds, internalizes, and clears von Willebrand factor and contributes to the variation in plasma von Willebrand factor levels. Blood 121,5228-37.

[139] Swystun, L.L., Notley, C., Georgescu, I., Lai, J.D. et al. (2019). The endothelial lectin clearance receptor CLEC4M binds and internalizes factor VIII in a VWF-dependent manner. Journal of Thrombosis \& Haemostasis 17,681-94.

[140] Chen, L. \& Zheng, S. (2020). Understand variability of COVID-19 through population and tissue variations in expression of SARS-CoV-2 host genes. Informatics in Medicine Unlocked 21,100443.

[141] Smith, N.L., Chen, M.H., Dehghan, A., Strachan, D.P. et al. (2010). Novel associations of multiple genetic loci with plasma levels of factor VII, factor VIII, and von Willebrand factor: The CHARGE (Cohorts for Heart and Aging Research in Genome Epidemiology) Consortium. Circulation 121,1382-92.

[142] Swystun, L.L., Ogiwara, K., Lai, J.D., Ojala, J.R.M. et al. (2019). The scavenger receptor SCARA5 is an endocytic receptor for von Willebrand factor expressed by littoral cells in the human spleen. Journal of Thrombosis \& Haemostasis 17,1384-96. 
[143] Wen, X., Wang, N., Zhang, F. \& Dong, C. (2016). Overexpression of SCARA-5 inhibits tumor proliferation and invasion in osteosarcoma via suppression of the FAK signaling pathway. Molecular Medicine Reports 13,2885-91.

[144] Lee, H., Lee, Y.J., Choi, H., Seok, J.W. et al. (2017). SCARA-5 plays a critical role in the commitment of mesenchymal stem cells to adipogenesis. Scientific Reports 7,14833

[145] Li, J., Liu, X. \& Zhang L. (2015). The role of bone marrow microenvironment in governing the balance between osteoblastogenesis and adipogenesis. Aging Diseases 7,514-25.

[146] Franchini, M. \& Mannucci, P.M. (203). Hemophilia A in the third millennium. Blood Reviews 27,179-84.

[147] Mahlangu, J.N. (2018). Bispecific antibody Emicizumab for haemophilia A: a breakthrough for patients with inhibitors. BioDrugs 32,561-70.

[148] Lenting, P.J., Denis, C.V. \& Chirstophe, O.D. (2017). Emicizumab, a bispecific antibody recognizing coagulation factors IX and X: how does it actually compare to factor VIII? Blood 130,2463-2468. 
Table 1 : Main hemophilia A therapies

\begin{tabular}{|c|c|c|}
\hline Therapeutic agents & Mechanism of action & Dosing frequency (prophylaxis) \\
\hline $\begin{array}{l}\text { Plasmatic FVIII concentrates } \\
\text { - Pure plasmatic FVIII } \\
\text { - Plasmatic FVIII with VWF }\end{array}$ & Replacement therapy with plasmatic FVIII & $\begin{array}{l}1 \text { to } 3 \text { times/week (i.v.) } \\
1 \text { to } 3 \text { times/week (i.v.) }\end{array}$ \\
\hline $\begin{array}{l}\text { Recombinant FVIII concentrates) } \\
\text { - rFVIII CHO } \\
\text { - rFVIII BHK } \\
\text { - rFVIII HEK }\end{array}$ & $\begin{array}{l}\text { Replacement therapy with recombinant FVIII } \\
\text { from animal or human cells }\end{array}$ & $\begin{array}{l}1 \text { to } 3 \text { times/week (i.v.) } \\
1 \text { to } 3 \text { times/week (i.v.) } \\
1 \text { to } 3 \text { times/week (i.v.) }\end{array}$ \\
\hline $\begin{array}{l}\text { Extended Half Life FVIII concentrates } \\
\text { - rFVIII PEG (rurioctocog alpha pegol, turoctocog } \\
\text { alpha pegol, damoctocog alpha pegol) } \\
\text { - rFVIII-Fc (efmoroctocog alpha) } \\
\text { - rFVIII single chain } \\
\text { - rFVIIIFc-VWF-XTEN (Bioverativ/Sanofi, SOBI) }\end{array}$ & $\begin{array}{l}\text { Replacement therapy with recombinant modified } \\
\text { FVIII (from CHO, BHK or HEK) which shows } \\
\text { extended half-life : Fc fusion, single chain factor } \\
\text { VIII or PEGylation }\end{array}$ & $\begin{array}{l}1 \text { to } 2 \text { times/week (seldom } 3 \text { times/week) (i.v.) } \\
1 \text { to } 2 \text { times/week (seldom } 3 \text { times/week) (i.v.) } \\
1 \text { to } 2 \text { times/week (seldom } 3 \text { times/week) (i.v.) } \\
1 \text { to } 2 \text { times/week (seldom } 3 \text { times/week), ongoing clinical } \\
\text { trial (i.v.) }\end{array}$ \\
\hline $\begin{array}{l}\text { Bispecific antibodies } \\
\text { - Emicizumab (Roche) } \\
\text { - Mim8 (NovoNordisk) }\end{array}$ & $\begin{array}{l}\text { Bispecific antibodies mimicking the action of } \\
\text { FVIII and allowing the activation of FX into FXa }\end{array}$ & $\begin{array}{l}\text { Once a week or } 1 / 2 \text { weeks or once monthly (s.c.) } \\
\text { Ongoing clinical trial (s.c.) }\end{array}$ \\
\hline $\begin{array}{l}\text { RNA inhibitors (si RNA) } \\
\text { - RNAi therapeutic targeting antithrombin } \\
\text { (Fitusiran) (Sanofi Genzyme) }\end{array}$ & $\begin{array}{l}\text { siRNA targeting the production of the most } \\
\text { potent physiological coagulation inhibitor }\end{array}$ & Once monthly, ongoing clinical trial (s.c.) \\
\hline $\begin{array}{l}\text { Anti-"Tissue Factor Pathway Inhibitor" } \\
\text { antibodies } \\
\text { - Concizumab (NovoNordisk) } \\
\text { - Befovacimab (Bayer) } \\
\text { - Marstacimab (Pfizer) }\end{array}$ & $\begin{array}{l}\text { Anti-TFPI monoclonal antibody that decreases } \\
\text { the inhibition of the FVIIa/tissue factor complex } \\
\text { after interaction with FXa and thus partially } \\
\text { restores thrombin generation }\end{array}$ & $\begin{array}{l}\text { Ongoing clinical trial (s.c.) } \\
\text { Once daily to once weekly, Ongoing clinical trial (s.c.) } \\
\text { Ongoing clinical trial (s.c.) } \\
\text { Ongoing clinical trial (s.c.) }\end{array}$ \\
\hline $\begin{array}{l}\text { Gene therapy } \\
\text { - ssAAV2/5-hFVIIIco-SQ (Biomarin) } \\
\text { - ssAAV2/LKO3-hFVIIIco-SQ (Sparks } \\
\text { Therapeutics) } \\
\text { - ssAAV2/8-hFVIII-SQ (Shire) } \\
\text { - ssAAV2/8-hFVIIIco-V3 (UCL/St Jude) }\end{array}$ & $\begin{array}{l}\text { Adeno-Associated Virus vectors providing the } \\
\text { patient liver with a cDNA sequence encoding a } \\
\text { functional FVIII }\end{array}$ & $\begin{array}{l}\text { Ongoing clinical trial (i.v.) } \\
\text { Ongoing clinical trial (i.v.) } \\
\text { Ongoing clinical trial (i.v.) } \\
\text { Ongoing clinical trial (i.v.) } \\
\text { Ongoing clinical trial (i.v.) }\end{array}$ \\
\hline
\end{tabular}

FVIII : Factor VIII, VWF : von Willebrand Factor, BHK cells : Baby Hamster Kidney cells ; CHO cells : Chinese Hamster Ovary cells ; HEK : Human

Embryo Kidney cells 
Table 2: Clinical trials studying the impact of haemophilia on bone mineral density

\begin{tabular}{|c|c|c|c|c|}
\hline Country & $\begin{array}{c}\text { Number of patients } \\
\text { enrolled }\end{array}$ & Ages (years) & $\begin{array}{l}\text { Bone parameters } \\
\text { in HA patients }\end{array}$ & References \\
\hline Australia & $\begin{array}{l}19 \mathrm{HA} \mathrm{A} \\
215 \text { age-matched } \\
\text { controls }\end{array}$ & $\begin{array}{l}\text { 5.73-18.5 } \\
\text { (Mean: 12.2) }\end{array}$ & - Lower BMD of lumbar spine & [28] \\
\hline Canada & $\begin{array}{l}18 \mathrm{HA} \mathrm{A} \text { and } \mathrm{B} \\
36 \text { age-matched } \\
\text { controls }\end{array}$ & $\geq 18$ & $\begin{array}{l}\text { - Vitamin D deficiency in } 41 \% \text { of } \\
\text { patients } \\
\text { - Lower distal tibia and radius total } \\
\text { BMD } \\
\text { - Lower trabecular BMD }\end{array}$ & [29] \\
\hline Colombia & $\begin{array}{l}79 \mathrm{HA} \mathrm{A} \text { and } 11 \mathrm{HA} \mathrm{B} \\
90 \text { age-matched } \\
\text { controls }\end{array}$ & $>5$ & $\begin{array}{l}\text { - Lower BMD of femoral neck and } \\
\text { hips } \\
\text { - Elevated C-reactive protein } \\
\text { levels in } 44.1 \% \text { of patients with } \\
\text { low BMD }(14.8 \% \text { in normal BMD) }\end{array}$ & [30] \\
\hline $\begin{array}{l}\text { Czech } \\
\text { Republic }\end{array}$ & $56 \mathrm{HA}$ & $\begin{array}{l}\text { Median: } 12.7 \\
(6.6-19.2)\end{array}$ & $\begin{array}{l}\text { - Lower BMD at distal radius in } \\
4 \% \text { of patients } \\
\text { - Lower BMC at the diaphysis } \\
\text { (total area and cortical thickness) } \\
\text { - HA patients significantly shorter } \\
\text { as compared to the national } \\
\text { reference data } \\
\text { - Sarcopenia in HA patients }\end{array}$ & [31] \\
\hline Egypt & $\begin{array}{l}30 \mathrm{HA} \\
30 \text { age-matched } \\
\text { controls }\end{array}$ & Mean: 4.97 & - lower BMD of lumbar spine & [32] \\
\hline Egypt & $\begin{array}{l}40 \mathrm{HA} \mathrm{A} \\
10 \text { age-matched } \\
\text { controls }\end{array}$ & Children & $\begin{array}{l}\text { - higher serum sclerostin level in } \\
\text { HA } \\
\text { Low BMD in } 37.5 \% \text { of patients }\end{array}$ & [33] \\
\hline Finland & $\begin{array}{l}31 \mathrm{HA} \mathrm{A} \text { and } \mathrm{B} \\
50 \text { age-matched } \\
\text { controls }\end{array}$ & $4-16$ & $\begin{array}{l}\text { - Lower whole body BMD } \\
\text { - Higher urine calcium secretion in } \\
\text { HA patients } \\
\text { - Urinary calcium excretion } \\
\text { correlated inversely with PTH and } \\
\text { positively with vitamin D } \\
\text { - No significant differences in the } \\
\text { bone turnover markers (PINP, } \\
\text { ICTP, ALP) } \\
\text { - Lower bone resorption marker } \\
\text { U-INTP in HA patients } \\
\text { - Higher serum Ca level in HA } \\
\text { patients }\end{array}$ & [34] \\
\hline Greece & $17 \mathrm{HA}$ & $4.94-18$ & $\begin{array}{l}\text { Only a small number of children } \\
\text { and young adults with hemophilia } \\
\text { have impaired bone properties }\end{array}$ & [35] \\
\hline Greece & $\begin{array}{l}100 \mathrm{HA} \mathrm{A} \text { and } \mathrm{B} \\
50 \text { age-matched } \\
\text { controls }\end{array}$ & Mean: 45.8 & $\begin{array}{l}\text { - Low BMD diagnosed in } 26.9 \% \\
\text { and } 20 \% \text { of HA and control } \\
\text { patients respectively } \\
\text { - Lower BMD in total hip, femoral } \\
\text { neck and great trochanter in HA } \\
\text { patients } \\
\text { - Vitamin D deficiency in } 50 \% \text { of } \\
\text { patients }\end{array}$ & [36] \\
\hline India & $\begin{array}{l}41 \text { (vs } 38 \text { age- } \\
\text { matched control } \\
\text { patients) }\end{array}$ & $2-18$ & $\begin{array}{l}\text { - Lower BMC and BMD } \\
\text { - High prevalence of low vitamin D } \\
\text { level } \\
\text { - Lower serum phosphorus was } \\
\text { and higher alkaline phosphatase }\end{array}$ & [37] \\
\hline
\end{tabular}




\begin{tabular}{|c|c|c|c|c|}
\hline & & & levels & \\
\hline Iran & $40 \mathrm{HA} \mathrm{A}$ and $\mathrm{B}$ & $>20$ & $\begin{array}{l}\text { - Lower BMD in } 58 \% \text { of patients } \\
\text { (osteopenia } 50 \% \text {, osteoporosis } \\
8 \% \text { ) }\end{array}$ & [38] \\
\hline Iran & $\begin{array}{l}42 \mathrm{HA} \mathrm{A} \\
\text { Age-matched controls }\end{array}$ & $\begin{array}{l}\text { 18-72 (Mean } \\
31.1)\end{array}$ & $\begin{array}{l}-45.2 \% \text { of osteopenia and } 28.6 \% \\
\text { of osteoporosis in the spine } \\
\text { and/or femur }\end{array}$ & [39] \\
\hline Iran & $\begin{array}{l}14 \text { HA B } \\
14 \text { age-matched } \\
\text { controls }\end{array}$ & $19-55$ & $\begin{array}{l}\text { - Lower BMD in femur regions } \\
\text { - Higher ALP and SGOT in HA } \\
\text { patients }\end{array}$ & {$[40]$} \\
\hline Israel & $\begin{array}{l}27 \mathrm{HA} \\
33 \text { age-matched } \\
\text { controls }\end{array}$ & $\begin{array}{l}\text { 7-17.7 } \\
\text { (Mean: 11.2) }\end{array}$ & $\begin{array}{l}\text { - Lower muscle strength } \\
\text { (especially limb's strength) } \\
\text { - No significant differences in } \\
\text { bone properties (evaluated by } \\
\text { bone speed of sound (SOS) } \\
\text { measurement) }\end{array}$ & {$[41]$} \\
\hline Italy & 70 & $\geq 18$ & $\begin{array}{l}\text { - Low BMD } \\
\text { of the femur }(74.2 \%,>30,<71) \\
52 \text { patients and of the lumbar } \\
\text { spine }(54.2 \%,<30 \text { y or }>71)\end{array}$ & [42] \\
\hline Italy & $\begin{array}{l}\text { HA A or B subdivided } \\
\text { into three groups of } \\
26 \text { patients each } \\
\text { (HIV- HCV } \\
\text { co- infected, HCV } \\
\text { mono- infected and } \\
\text { uninfected }\end{array}$ & $20-73$ & $\begin{array}{l}\text { - Lower bone mineral density and } \\
\text { hypovitaminose } D \text { in co-infected } \\
\text { groups } \\
\text { - Co-infection as comorbidity } \\
\text { factor }\end{array}$ & [43] \\
\hline Mexico & $69 \mathrm{HA} \mathrm{A}$ & $6-16$ & $\begin{array}{l}\text { - Lower BMD in } 34.7 \% \text { of } \mathrm{HA} \\
\text { patients } \\
\text { - Lower osteocalcin concentration } \\
\text { in HA patients and no significant } \\
\text { difference in C-telopetide levels } \\
\text { compared to the reference data }\end{array}$ & {$[44]$} \\
\hline Sweden & $\begin{array}{l}26 \text { severe } \mathrm{HA} \mathrm{A} \text { or } \mathrm{B} \\
16 \text { mild HA A or B } \\
\text { All patients received } \\
\text { prophylactic } \\
\text { treatment }\end{array}$ & $\begin{array}{l}>18 \text { and }< \\
65 \\
.40 .2+/-3.3 \\
(\text { severe } \mathrm{HA}) \\
33.6+/-2.1 \\
\text { (mild HA) }\end{array}$ & - No BMD alteration & [45] \\
\hline Sweden & $\begin{array}{l}39 \mathrm{HA} \mathrm{A} \text { and B } \\
\text { Group } A \quad \text { (started } \\
\text { prophylaxis at age of } \\
\leq 3 \text { years; } n= \\
22 \text { ); Group } B \text { (at age } \\
\text { of }>3 \text { years; } n= \\
15)\end{array}$ & $\begin{array}{ll}\text { Mean: } & 26 \\
(\mathrm{HA} \mathrm{A}), & 42 \\
(\mathrm{HA} \mathrm{B}) & \end{array}$ & $\begin{array}{l}\text { - Group A : BMD similar to the } \\
\text { reference population } \\
\text { - Groupe B : lower BMD } \\
\text { compared to the reference } \\
\text { population }\end{array}$ & {$[46]$} \\
\hline Turkey & $\begin{array}{l}41 \mathrm{HA} \mathrm{A} \text { (vs } 40 \\
\text { control patients) }\end{array}$ & $\begin{array}{l}18-56 \\
\text { (median: 26) }\end{array}$ & $\begin{array}{l}\text { - Lower femoral neck and total hip } \\
\text { BMD - Osteoporosis in } 60 \% \text { of } \\
\text { cases } \\
\text { - Osteopenia in } 20 \% \text { of cases } \\
\text { - Vitamine D insufficiency or } \\
\text { deficiency in } 60 \% \text { of cases }\end{array}$ & {$[47]$} \\
\hline Turkey & $51 \mathrm{HA} \mathrm{A}$ and $10 \mathrm{HA} \mathrm{B}$ & $\begin{array}{l}20-63 \\
\text { (average : } \\
37.8)\end{array}$ & $\begin{array}{l}\text { - Low BMD in } 48 \% \text { of patients } \\
\text { - No correlation between BMD } \\
\text { and vitamin levels }\end{array}$ & [48] \\
\hline Turkey & 39 & Children & $\begin{array}{l}\text { - Low BMD in } 78.4 \% \text { of patients } \\
\text { - Vitamin D deficiency in } 87.2 \% \text { of }\end{array}$ & [49] \\
\hline
\end{tabular}




\begin{tabular}{|c|c|c|c|c|}
\hline & & & $\begin{array}{l}\text { patients } \\
\text { - Negative correlation between } \\
\text { PTH and Z-score }\end{array}$ & \\
\hline Turkey & $29 \mathrm{HA} \mathrm{A}$ and $6 \mathrm{HA} \mathrm{B}$ & $>18$ & $\begin{array}{l}\text { - Lower BMD ( } 34 \% \text { decrease) } \\
\text { - Lower levels of vitamin D, } \\
\text { calcium and testosterone } \\
\text { - Higher levels of PTH, PINP and } \\
\text { activated partila thromboplastin } \\
\text { time } \\
\text { - No significant difference in NLR, } \\
\text { PLR, phosphorus, thyroid- } \\
\text { stimulating hormone, and UNTX } \\
\text { levels }\end{array}$ & {$[50]$} \\
\hline Turkey & $39 \mathrm{HA} \mathrm{A}$ and $10 \mathrm{HA} \mathrm{B}$ & $\begin{array}{l}\text { average } 36 \pm \\
11.35\end{array}$ & $\begin{array}{l}\text { - Lower BMD in } 34.8 \% \text { of patients } \\
\text { of less than } 50 y \\
\text { - Osteoporosis in } 66.6 \% \text { of } \\
\text { patients older than } 50 y \\
\text { - Vitamin D deficiency in } 77.5 \% \text { of } \\
\text { patients with no correlation with } \\
\text { BMD }\end{array}$ & [51] \\
\hline Turkey & $\begin{array}{l}44 \mathrm{HA} \\
40 \text { age-matched } \\
\text { controls }\end{array}$ & $3-18$ & $\begin{array}{l}\text { - lower BMD of lumbar spine } \\
\text { - Higher levels of PTH levels in } \\
\text { HA patients } \\
\text { - Lower concentrations of vitamin } \\
\text { D, osteocalcin, calcitonin }\end{array}$ & [52] \\
\hline UK & $37 \mathrm{HA} \mathrm{A}$ & $>18$ & $\begin{array}{l}\text { - } 5 \% \text { of osteoporosis } \\
\text { - Lower BMD in } 24 \% \text { of patients } \\
\text { - Vitamin D deficiency in } 91 \% \text { of } \\
\text { patients similarly to the control } \\
\text { group }\end{array}$ & [53] \\
\hline USA & $\begin{array}{l}316 \mathrm{HA} \mathrm{A} \\
\text { and } 66 \mathrm{HA} \mathrm{B}\end{array}$ & $\begin{array}{c}20 \text { (HA A) } \\
26 \text { (HA B) }\end{array}$ & $\begin{array}{l}\text { - Higher fracture incidence }(24 \cdot 8 \\
\text { fractures per } 1000 \text { patient- years, } \\
\text { than } 9 \cdot 6 \text { fractures per } 1000 \\
\text { patient- years in the control } \\
\text { population) }\end{array}$ & {$[54]$} \\
\hline USA & $88 \mathrm{HA} \mathrm{A}$ and $\mathrm{B}$ & Median : 41 & $\begin{array}{l}-<50 y: \text { low BMD (21\%) and low } \\
\text { normal BMD (39\%) } \\
\text { The low BMD was independently } \\
\text { associated with increasing } \\
\text { hemophilic arthropathy } \\
->50 y: \text { osteoporosis (38\%), } \\
\text { osteopenia (42\%) }\end{array}$ & [55] \\
\hline USA & $\begin{array}{l}25 \mathrm{HA} \mathrm{A} \\
5 \mathrm{HA} \mathrm{B}\end{array}$ & $\begin{array}{l}18-66 \\
\text { (Median: } \\
41.5)\end{array}$ & $\begin{array}{l}\text { - Lower BMD in the lumbar spine } \\
(20 \%), \text { femoral neck }(47 \%), \text { hip } \\
(20 \%) \\
\text { - Osteopenia in HA patients (43\%) } \\
\text { - Osteoporosis in HA patients } \\
(27 \%) \\
\text { - No significant differences in } \\
\text { ALP, TSH, calcium, testosterone } \\
\text { - Correlation between vitamin D } \\
\text { levels and osteoporosis }\end{array}$ & {$[56]$} \\
\hline
\end{tabular}

HA : Hemophilia ; BMD : Bone Mineral Density ; SGOT : serum glutamic oxaloacetic transaminase 


\section{Figure Legends}

Figure 1: The extrahemostatic functions of FVIII. Recent data from the literature highlighted the non-hemostatic activities of FVIII, including bone, inflammatory and vascular systems. By interacting with Osteoprotegerin (OPG) and Receptor of Nuclear Factor Kappa B Ligand (RANKL), the FVIII-VWF complex regulates osteoclast formation and bone resorption. FVIII appears to regulate osteoblast activity via the thrombin and ProteaseActivated Receptor (PAR) -1 pathways. Sexual dimorphism can be associated with the mechanism driving bone regulation. FVIII is implicated in the inflammatory process by modulating macrophage polarization. Macrophages also contribute to the clearance of FVIII. Large blood neovessels with increased permeability have been described in the synovial tissues of hemophilia patients, as well as in FVIII knockout mice.

Figure 2: The main receptors controlling the bioavailability of FVIII and VWF. Blood circulating FVIII is a divalent metal ion-dependent heterodimer composed of a light chain (C1-C2-A3 domains) and a heavy chain (A1-12-B). Proteolytic cleavage of FVIII leads to an active form of FVIII with is composed of a heterotrimer. The monomer C1-C2-A3 is linked to the monomer A1 in a divalent metal ion-dependent manner and the monomer A2 binds to the two monomers via electrostatic interactions. In addition to VWF, which interacts with FVIII and increases its half-life, several other receptors of FVIII have been described. Low density Lipoprotein Receptor-Related Protein 1 (LRP-1), asialoglycoprotein receptor (ASGPR), sialic acid binding immunoglobulin-like lectin-5 (Siglec-5), stabilin-2 (STAB-2), C-type lectin domain family 4 member M (CLEC4M), and Scavenger Receptor Class A Member 5 (SCARA-5) can bind to FVIII and control its clearance. In addition to regulating FVIII or the bioavailability of the FVIII-VWF complex, these binding molecules may modulate their 
biological functions. SRCR: Scavenger receptor cysteine-rich; VNTR: Variable number of tandem repeats. 


\section{Figure 1}

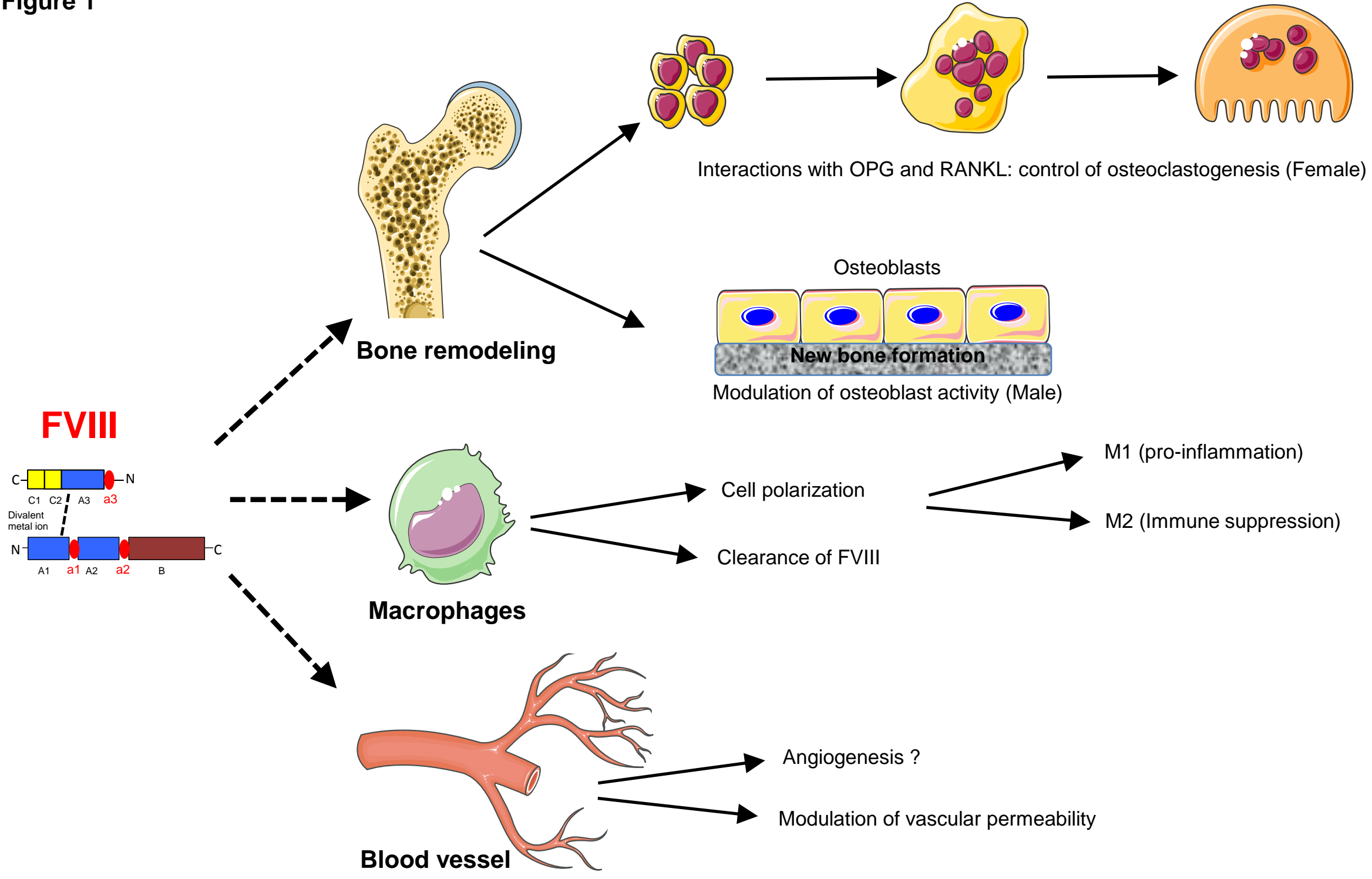




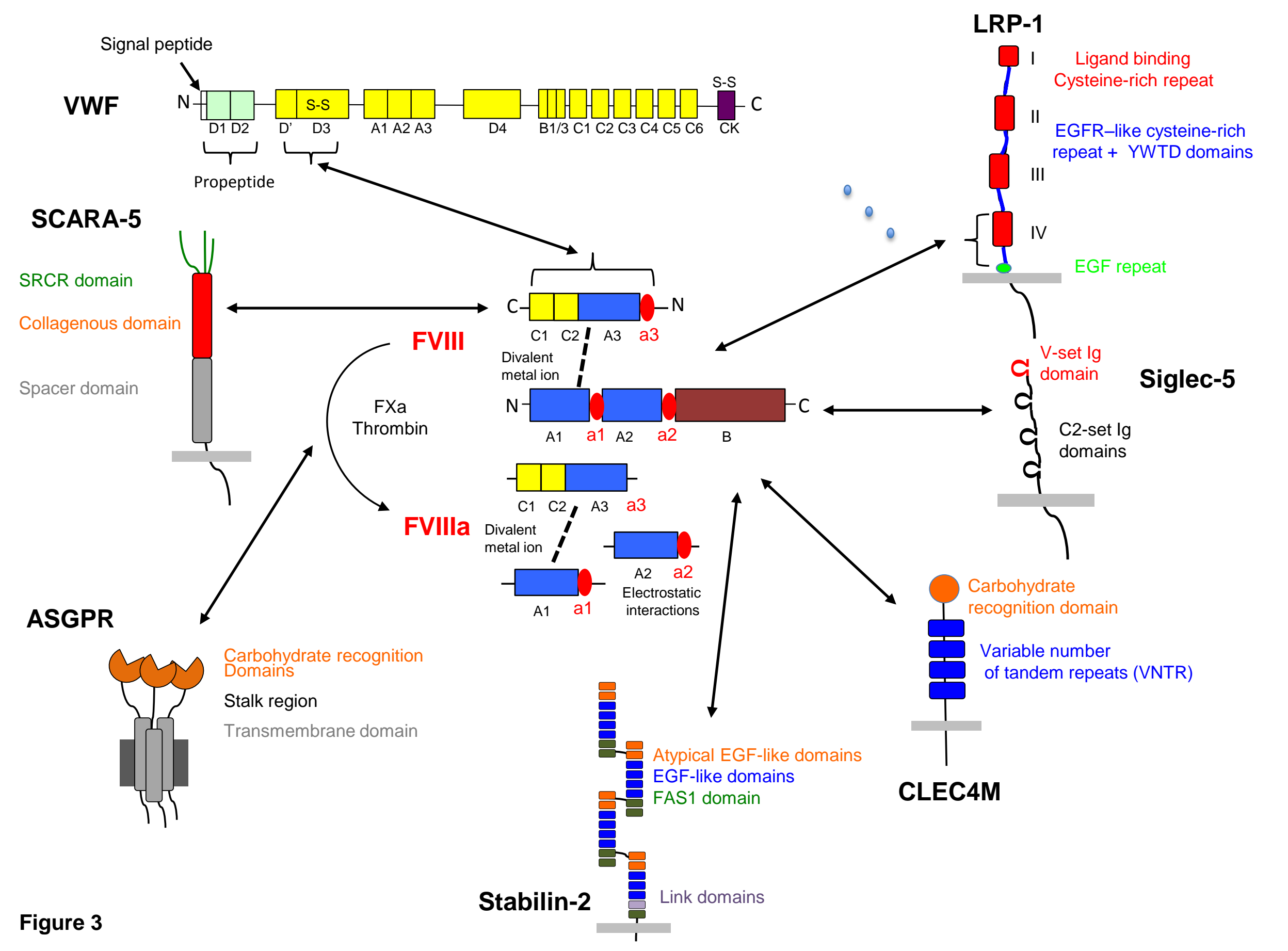

